NBER WORKING PAPER SERIES

\title{
THE MARKET FOR \\ AMERICAN STATE GOVERNMENT BONDS \\ IN BRITAIN AND THE UNITED STATES, 1830 TO 1843
}

\author{
Namsuk Kim \\ John Joseph Wallis \\ Working Paper 10108 \\ http://www.nber.org/papers/w10108
}

\author{
NATIONAL BUREAU OF ECONOMIC RESEARCH \\ 1050 Massachusetts Avenue \\ Cambridge, MA 02138 \\ November 2003
}

This paper was presented at the Cliometrics Society meetings in Raliegh, 2003 and the EHA meetings in Nashville, 2003. Helpful comments were received from Howard Bodenhorn, Ben Chabot, Richard Sylla, and Ed Perkins. The views expressed herein are those of the authors and not necessarily those of the National Bureau of Economic Research.

(C)2003 by Namsuk Kim and John Joseph Wallis. All rights reserved. Short sections of text, not to exceed two paragraphs, may be quoted without explicit permission provided that full credit, including $(\mathrm{C}$ notice, is given to the source. 
The Market for American State Government Bonds in Britain and the United States, 1830-1843 Namsuk Kim and John Joseph Wallis

NBER Working Paper No. 10108

November 2003

JEL No. N0, N1, N2, N4

\section{$\underline{\text { ABSTRACT }}$}

In the 1830s the British and American economies were hit by a series of shared macroeconomic shocks. This paper investigates the role of markets for Americas State bonds in Britain and the U.S. during and between the crises in 1837,1839 , and 1842 . There is strong evidence that the crises in 1839 and 1842 originated in the U.S. and spread to Britain. There is also strong evidence that credit markets for American state bonds were tighter in the U.S. than in London between 1839 and 1842.

Namsuk Kim

Department of Economics University of Maryland

College Park, MD 20742

kim-ns@econ.umd.edu

John Joseph Wallis

Department of Economics

University of Maryland

College Park, MD 20742

and NBER

wallis@econ.umd.edu 
During the 1830s and 1840s, the British and American economies experienced a series of shared macroeconomic fluctuations. A sharp financial crisis in May of 1837 was followed by a brief recovery in 1838 and 1839. A second financial crisis in October of 1839, while less severe than the panic in 1837 , nonetheless produced a recession and deflation that lasted until 1843. A third financial crisis, in the winter of 1842, affected primarily the United States, although conditions continued to deteriorate in Britain through 1842 as well. The two economies were closely linked by trade and finance, leading historians to speculate about the role of each country in provoking the crises. Temin's Jacksonian Economy attributes the Panic of 1837 and the Crisis of 1839 to the Bank of England and international factors, absolving the Bank of the United States, Nicholas Biddle (the bank's president from 1823 to 1839), and President Andrew Jackson. Biddle himself criticized the Bank of England for its policies in 1839, as did Jenks and Hammond. ${ }^{1}$ On the other side, in $A$ Study in Trade-Cycle History, Matthews concluded that '... it is in the nature of things futile to try and draw any hard-and-fast line assigning to either country causal primacy in the cycle as a whole or in its individual phases. But enough has been said in the present chapter to indicate the powerful nature of forces making for instability from within the United States in this period.' 2

The market for American state debts played a central role in financial relationships between Britain and the United States in the 1830s. In the mid-1830s American states embarked on a internal improvement boom, raising the amount of state debt outstanding from $\$ 81$ million in 1835 to $\$ 198$ million in 1842 . American states authorized and issued bonds worth $\$ 13$ million in 1836, \$21 million in 1837, \$35 million in 1838, \$22 million in $1839, \$ 19$ million in 1840 , and $\$ 6$ million in 1841 . By 1841 , estimates are that half of the $\$ 200$ million in state debt 
was held abroad, primarily in Britain. ${ }^{3}$ State bonds provided a critical link between financial markets in the two countries. By 1836, state bonds were the only long-term American debt instrument traded in Britain because the United States retired all its federal debt in 1835 . The single American corporation whose stock traded regularly in London was the Second Bank of the United States, which lost its national charter in 1836. Millions of dollars of identical state bonds traded in London, New York, and Philadelphia. Movements in bond prices give us a window into the connections between British and American financial markets.

The boom in state transportation and banking projects, and the associated wave of new state bond issues, also play a critical role in our understanding of macroeconomic events. Temin attributed the quick recovery of the American economy from the Panic of 1837 to state expenditures for canals and railroads, financed largely by British lending. 'The recession of $1837-38 \ldots$ was brought to a speedy end by the restoration of the capital flow from Britain to the United States and by the expansion of demand stemming from the rise in state government expenditures.' Temin attributed the 1839 crisis to credit tightening by the Bank of England and the long recession that followed to tightening markets in Britain for American state debts: 'The state projects initiated in the late 1830s had been started in the expectation of external [British] financing.... Unfortunately, the new inflow of foreign capital did not continue [in 1839]... and the manifold projects of the states were abandoned.' ${ }^{4}$ By the summer of 1842, eight states and the Territory of Florida were in default on their debts, and Mississippi and Florida had repudiated their bonds outright. The collapse of state credit was the most serious consequence of the depression that began in $1839 .^{5}$

Our purpose here is to determine whether credit markets for American state bonds in and between the three major financial crisis were tighter in the United States or in Britain, and whether shocks to the bond markets originated in the United States or in London. We ask three questions. First, were British and American financial markets well integrated? Not surprisingly, 
we find that they were. Financial markets effectively arbitraged the prices of American state bonds in London and the U.S. within a band attributable to the high transaction costs of transAtlantic commerce in this period. Because markets were integrated we can ask whether the pattern of bond price movements in the Crisis of 1839 and the Collapse of 1842 were consistent with shocks originating in the United States, in Britain, or neither country. We find clear evidence that shocks in both crises originated in the United States. Finally, we ask whether bond price movements suggest that British investors were unwilling to lend to America after 1839. We find that yields on American state bonds in 1840 and 1841 tended generally to be lower in London than they were in the United States, suggesting that British lenders purchased American state debt on favorable terms relative to lenders in New York and Philadelphia. The crises in 1839 and 1842 began in the United States, and between the two crises credit markets for state debt in the United States demanded higher yields and paid lower prices on American state bonds than did markets in London. We find little evidence that the market for state bonds collapsed because of pressures emanating from Britain. In the final section of the paper we identify the forces operating in America, neglected in virtually all accounts of this era, that produced the collapse.

\section{The History}

The early 1830 s were a period of general economic expansion in both Britain and the United States, marred by a brief recession in 1834. The expansion turned into a boom in 1835 , driven by a rapid increase in public land sales in the United States. The boom was reflected in rising prices in both countries, an increase in international trade, and an increase in the flow of capital from Britain to the United States. Prices stopped rising in early 1837, and a sharp break in cotton prices combined with tight credit conditions in Britain and the United States to produce a financial panic in May of 1837. In the United States the panic resulted in the suspension of 
specie payments by banks throughout the country, and in Britain the failure or near failure of several large commercial houses engaged in the American trade. The Bank of England did its part to bring about the panic by raising the Bank Rate from 4 to 6 percent and, significantly, by refusing to discount bills arising from the American trade in July of 1836. 'A part of this action was the absolute refusal of the Bank's Liverpool Agent, no doubt under orders, to handle paper drawn from America on those firms. ${ }^{96}$ Figure 1 shows the Bank Rate, short term interest rates in London and New York, and the New York price of 60 day bills payable in London.

The effects of financial tightening were compounded in the United States by the decision of the federal government to distribute the federal fiscal surplus of $\$ 36$ million to the states in 1837, and by President Jackson's specie circular requiring that all public land purchases be redeemed in specie. The two measures together disrupted the normal allocation of gold reserves within the banking system, further exacerbating the liquidity problems of New York banks brought on by tightening international markets. ${ }^{7}$

The Panic of 1837 was followed by a year of bank specie suspensions in the United States, financial distress in Britain, deflation in both countries, and a sharp decline in the volume of trade in 1838. But the recession was shortlived. By the fall of 1838 land sales, international trade, prices, and capital flows had all turned up again. Banks in the United States resumed specie payments in the summer of 1838. As Temin stressed, the quick recovery in the United States was partly the result of fiscal stimulus created by the rapid expansion of state borrowing to build canals, railroads, and banks. Mid-Atlantic states had been borrowing since the 1820 s to build canal networks, beginning with New York's Erie Canal in 1817. In 1836 a second wave of borrowing began, both in the older states - New York, Pennsylvania, Maryland, and Ohio - and in a new group of states in the west - Indiana, Illinois, Michigan, Arkansas, and Mississippi. Table 1 provides debt authorized by year from 1830 to $1841 .^{8}$ This was peacetime fiscal 
expansion on a scale never witnessed in the young United States.

The transportation boom, however, died quickly in the Northwest. Indiana, Illinois, and Michigan all sold bonds on credit to eastern investment banks. These new states issued bonds for which they were liable for interest payments immediately, but for which they would receive payments only in installments. ${ }^{9}$ In July of 1839 , the Morris Canal and Banking Company of New Jersey defaulted on Indiana, and the state quickly was forced to curtail construction on its network of canals and railroads. By the fall, Illinois and Michigan were forced to slow or stop construction when investment banks defaulted on their obligations to the states. Land sales and land values in these northwestern states had been rising steadily through the $1830 \mathrm{~s}$. When transportation construction stopped, land values and property tax revenues began falling and, by late 1839, it was apparent that these states would soon have trouble servicing their debts. ${ }^{10}$ In January of 1841, Indiana was the first state to default on interest payments. Table 2 lists the states that defaulted on interest payments, the date of default, whether the state resumed payments or repudiated their debts, and if they resumed, the date of resumption.

The collapse of internal improvement projects in the Northwest was not the only economic problem in 1839. The Bank of England, again facing drains on its specie reserves, began raising the Bank Rate in the summer (Figure 1). A crisis broke out in the United States when the Bank of the United States of Pennsylvania (the BUSP) suspended specie payments in October. This was followed by suspensions throughout the western and southern parts of the United States, but not in New York and New England. As Hammond and Smith emphasize, the BUSP's immediate problem in 1839 was domestic, not foreign. Pressure from New York and Boston banks forced the BUSP to suspend. ${ }^{11}$

Although 1839 marked the end of the Northwestern transportation boom, New York, Ohio, and Pennsylvania continued to authorize new debt issues for their canals (Table 1). Despite rising interest rates, 1838,1839 , and 1840 were years of substantial state borrowing. We 
can test Temin's conjecture that the end of British willingness to lend to American states after 1839 brought on the crisis and contributed to the depression that followed. Figure 2 shows average yields to maturity in the London market between 1831 and 1843 for the bonds of New York, Pennsylvania, Ohio, Indiana, Illinois, and Massachusetts. Figure 3 provides similar average yields in the United States for the bonds of New York, Pennsylvania, Ohio, and

Illinois. ${ }^{12}$ Economic historians have tended to focus on the Panic of 1837 , to pay some attention to the Crisis of 1839, and to ignore the Collapse of 1842. The figure suggests we may have missed the biggest crisis of them all. What happened in 1842 ?

\section{Market Integration}

Figures 2 and 3 are constructed from data collected by Richard Sylla, Jack Wilson, and Robert Wright (SWW). ${ }^{13}$ They gathered quotations on debt and equity prices from contemporary newspapers in London, New York, Philadelphia, Boston, Baltimore, and other American cities. ${ }^{14}$ Prices are available for American markets from the early 1790s up to the 1850s. Prices in London are only available from 1811 to 1843 . State government bonds typically traded in New York, Philadelphia, and London, as well as in the regional market of issue (for example, Maryland bonds in Baltimore and Massachusetts bonds in Boston). SWW list over 100 bonds from 18 states trading at some point in London. Trading occurred in new issues and the secondary market. Bonds traded actively for a few months after they were issued, but perhaps because bonds were held mostly by long-term investors, relatively few bonds continued to trade regularly in the secondary market. The most consistent series are available for New York, Pennsylvania, and Ohio.

New issues were marketed by the states themselves and through the agency of investment banking intermediaries. Legislation authorizing bond issues typically required that bonds be sold at par or better. The par restriction clearly applied to new issues marketed by 
states, sometimes applied to issues by intermediaries, and never applied to the secondary market. ${ }^{15}$ When prices in the secondary market dropped below par, states and their agents could not sell new bonds at par. States could accurately claim that new bonds could not be sold in New York or London, even when simultaneously there was an active secondary market in state bonds in both markets. What states often failed to say is that there was no market for bonds with par sales restrictions when the market price fell below par. The inability of states to market their bonds was usually a function of their unwillingness (or their agents' inability) to borrow at higher interest rates. States that were willing to borrow at market rates could always borrow.

Fortunately, most state bonds are reported with their yield and maturity, e.g., 'New York 5's 1854 .' This enables us to calculate, for each individual bond, its yield to maturity. ${ }^{16}$ For each state we calculate the average yield to maturity for all the bonds traded in each market, e.g., 'Ohio Bonds trading in New York.' This is a simple average because there is no information available on trading volumes to provide us with weights. There are often significant gaps in the series, and some of the short-term fluctuation results from changes in the bonds reported in a particular week. The 'United States' yields we quote for Ohio, New York, and Illinois bonds come from the New York market, and for Pennsylvania bonds the yields are from the Philadelphia market.

Visual examination of the bond yields in Figures 2 and 3 suggests that the market for state bonds in London and in the United States were closely related. To investigate the relationship more formally, we ran a series of ARCH tests. $\mathrm{Y}_{\mathrm{it}}$ is $\log$ of the average bond yield in country ' $i$ ' on date ' $t$ ', $a_{i}$ is the constant term for country $i$, and $\varepsilon_{i t}$ is the market specific disturbance term:

(1) $Y_{\text {it }}=a_{i}+\varepsilon_{\text {it }}$

The errors in equation (1) follow a multivariate normal distribution with auto regressive conditional heteroscedasticity (ARCH): ${ }^{17}$ 
(2) $\quad \mathrm{E}\left(\varepsilon_{\mathrm{it}}\right)=\mathrm{a}_{\mathrm{ij}}+\mathrm{b}_{\mathrm{ij}} \mathrm{E}\left(\varepsilon_{\mathrm{it}-1} \varepsilon_{\mathrm{jt}-1}\right)$

The dependent variable, $\mathrm{Y}_{\mathrm{i}}$ is average yield to maturity (YTM) in market $\mathrm{i}$, of bonds that were commonly traded in both markets. The $\mathrm{a}_{\mathrm{i}}$ are constant terms measuring the log of the average bond yield in each market. The $\mathrm{a}_{\mathrm{ij}}$ estimate the constant element of the covariance between yields in the two markets. In an integrated market the $\mathrm{a}_{\mathrm{ij}}$ should be close to zero. The $b_{i j}$ estimate the effect of the lagged disturbances on the covariance between the prices in the two markets. The $b_{i j}$ measure whether the covariance of the disturbances are related to lagged disturbances. That is, for example, whether last period's errors in London affects this period's errors in New York. In an integrated market the $b_{i j}$ should be close to one. If the errors in the two markets were related, and they were, this is evidence that the two markets were integrated.

The calculation of YTM of a bond requires the maturity, coupon rate and the weekly prices of the bond, and there are missing observations on $\mathrm{Y}$ when not all of these data are available. Missing observations can be dealt with in several ways. First, we linearly interpolate for the unobserved data, and then run regressions using weekly and monthly data. ${ }^{18}$ Second, monthly data contain far fewer missing observations and give us a check on the robustness of the results using weekly data, but at a loss of significant number of observations. The monthly data are realistic, however, given the time lags involved in the flow of information between the U.S. and Britain in the early $19^{\text {th }}$ century. Finally, we estimate a regression using only observed weekly data, using our own method of analysis (described in the appendix) to account for missing observations.

The regression results are provided in Table 3. The first column uses the weekly sample of linearly interpolated bond yields, the second column the monthly sample of linearly interpolated yields, and the third column is based only on the observed monthly data using our adjustment for missing observations. The results indicate strong evidence for integration. The constant covariance of returns in the two markets, the $\mathrm{a}_{\mathrm{ij}}$, are very close to zero. The effect of 
lagged disturbances on the covariance of returns, the $b_{\mathrm{ij}}$, are positive and very close to one, indicating that shocks to one market are quickly reflected in yields in the other market. These results are unaffected by the use of linearly interpolated weekly or monthly data, or controlling for the presence of missing observation in the design of the estimator.

For comparison, Table 4 performs a similar exercise on stock price indexes in London and in American markets. Missing observations are not a problem with the market indices. We have run regressions on weekly prices, the change in weekly prices, and monthly prices. Unlike the bond markets, where the underlying securities are the same in both markets, the equities traded in the London market are different from the equities in the American markets. As with the bond market, however, there is substantial evidence of market integration.

Although the markets were well integrated, transacting between the two markets were not costless. Differences in interest rates between London and New York of one half to a whole percentage point in yields (100 basis points) often persisted for several months, longer than the one to two-month time it took for news to travel across the ocean. We should not be surprised by this, for in the $1830 \mathrm{~s}$ bank notes of Philadelphia banks typically traded at a $1 / 4$ to $1 / 2$ percent discount in New York in times when there was no default risk. The discount merely reflected the time and effort involved in presenting the bank note to the issuing bank for redemption. It was possible for bond yields to be higher in New York than in London, but not too much higher. III. American State Bonds in London and the United States:

Figures 2 and 3 show the average yields of state bonds traded in London and the United States, but disentangling what happened in the three financial crises requires examining states individually. The five largest state borrowers were Pennsylvania, Louisiana, New York, Ohio, and Maryland (Table 1). Louisiana and Maryland were not steady borrowers and we do not have consistent records on their bond yields. New York began borrowing in 1817 and Ohio in 1825. 
Both states completed their major canal projects in the early 1830s. Both states resumed borrowing in 1837 , and borrowed heavily and regularly through 1842 . Hence, there are long and fairly complete bond yields for those states before 1834 and after 1837, but only sporadic information in 1835, 1836, and 1837. Pennsylvania began borrowing in the 1820 s and continued to borrow through the 1830 s, so there are long and fairly complete records for Pennsylvania. Illinois, Indiana, and Massachusetts did not begin borrowing heavily until 1837 . We have only sporadic quotations for those three states. We focus, therefore, our anaylsis on the bonds of New York, Ohio, and Pennsylvania.

Table 5 gives average bond yields to maturity for New York and Ohio bonds in both London and the United States by year from 1831 to 1836 and by quarter from 1837 to 1843 ; the standard deviation of the yields in each year; and the average difference in yields in the two markets. ${ }^{19}$ Figures 4 and 6 graph weekly bond yields for New York and Ohio bonds in both markets, and Figures 5 and 7 graph the contemporaneous U.S.-London difference in yields for New York and Ohio bonds. Table 6 presents the same information for Pennsylvania bonds, as well as the difference between the yield of Pennsylvania bonds in Philadelphia and the average yield of New York and Ohio bonds in New York. Figures 8 and 9 graph Pennsylvania bond yields in Philadelphia and London, and the U.S.-London difference in yields. Table 7 presents the infrequently reported yields we have for Illinois, Massachusetts, and Indiana.

The individual state series show the same pattern as the aggregate series: bond yields rise gradually in 1837 , rise sharply in the fall of 1839 , and rise and fluctuate wildy in the winter of 1842. The spread in bond yields between the U.S. and London, however, moved differently in each crisis. The bond yield spreads reflect how expectations and information differed in the United States and London. To exploit the yield spreads, however, we first need to appreciate the 
situation in Pennsylvania.

Pennsylvania:

New York began the Erie Canal in 1817 and completed it in 1825; Ohio began construction on two canals in 1825 and completed them in 1832; and Pennsylvania began work on its canal system in 1826 and completed the Main Line in 1835. By 1836, the New York and Ohio canals were returning revenues to the state Treasury in excess of operating costs and interest payments, while the Pennsylvania canals were a financial disaster. Financial markets priced the bonds of the three states accordingly. In the early 1830s, yields on Pennsylvania bonds were consistently higher than the yields on New York and Ohio bonds, usually 0.5 percent or more (Table 6, column 5). ${ }^{20}$

Pennsylvania's situation changed in 1836. When Nicholas Biddle lost the Bank War to Andrew Jackson, the Bank of the United States sought a charter from the state of Pennsylvania. In 1836, the BUS was rechartered as the Bank of the United States of Pennsylvania. The charter was very generous to the state, including a promise by the BUSP to underwrite $\$ 6$ to $\$ 8$ million in state bond issues:

The Bank committed to pay an additional "twenty installments of $\$ 100,000$ each, beginning June 1, 1836 and continuing for the next nineteen years, to pay $\$ 500,000$ on March 3, 1837, to subscribe for various specifically designated public improvement stocks amounting to $\$ 675,000$, to make long term loans to the state up to $\$ 6,000,000$ for which the state agreed to turn over to the Bank bonds redeemable in 1868 (at par if they were 4 per cent bonds at one hundred and ten if they were 5's) and to make temporary loans up to a maximum of $\$ 1,000,000$ in any one year at 4 per cent interest." (Smith, Economic Aspects, p. 179)

In 1837 , the yields on Pennsylvania bonds suddenly became fixed within narrow limits.

Between November 1837 and April 1839 the maximum yield on Pennsylvania bonds in Philadelphia was 4.65 percent, the minimum yield was 4.42 percent (Table 6). The standard deviation on the Pennsylvania yield in 1838 was .02 percent, the lowest standard deviation for 
any state's bonds in any year in Tables 5, 6, and 7. Deliberately or not, the BUSP pegged the price of Pennsylvania bonds as a result of its obligations to purchase state bonds over this 18 month period. Other lenders were not so optimistic about Pennsylvania, however. From 1837 to 1840 yields on Pennsylvania bonds in London remained considerably higher than yields in Philadelphia. ${ }^{21}$

The BUSP's condition worsened in 1839, when its extensive operations in the state bond market, the cotton market, and the market for international and domestic exchange went sour. ${ }^{22}$ In October of 1839, the BUSP was forced to suspend convertibility of its demand liabilities into specie because of a run by New York and Boston Banks. The suspension of payments precipitated a banking crisis in the United States; with banks in the south and west suspended until 1842. But the suspension did not release the BUSP from its obligations to the state of Pennsylvania. Until early 1841, although the BUSP no longer pegged the yield, Pennsylvania bonds continued to enjoy lower yields in Philadelphia, despite steady borrowing by the state, than did the bonds of Ohio and New York in New York or London.

In February 1841, the state attempted to force the BUSP to resume specie payments, whereupon the bank closed its doors and went out of business. With BUSP out of the market, yields on Pennsylvania bonds in Philadelphia jumped immediately, from 6.01 percent on January 2 to 9.5 percent on March 7. For the remainder of 1841, Pennsylvania bond yields were above 8 percent in Philadelphia, and prices on Pennsylvania bonds were no longer quoted in London. Yields on Pennsylvania bonds were now 2 percentage points higher than yields on New York and Ohio bonds. The BUSP's artificial support of state credit between 1837 to 1840 makes problematic the use of Pennsylvania bond prices as a indicator of market conditions in those years.

Pennsylvania was in deep financial trouble in 1841 . The state's credit returned to a level 
consistent with its financial situation when the failure of the BUSP forced the state back into regular credit markets. In late 1841, yields on Pennsylvania bonds in Philadelphia began rising rapidly. Pennsylvania defaulted on its bond obligations in 1842, with devastating consequences for the state bond market on both sides of the Atlantic.

The Crises of 1837 and 1839:

The Panic of 1837 occurred in a window of time where bond price data are hard to come by. First, New York completed work on its canals in the 1820s and Ohio in the early 1830s. New York paid off most of its debt by 1835. Although both New York and Ohio started new projects in 1836 (New York authorized a \$2,000,000 bond issue in 1836), neither state borrowed heavily until later in 1837. As a result, there are gaps in the quotation series for both states in 1837, reflecting the absence of marketable bonds in both New York and London. Second, western states had just begun issuing bonds when the Panic hit, and we do not have usable price series for Indiana or Illinois in 1837. With the exception of Pennsylvania, not many state bonds traded in the spring of 1837.

Between 1831 and 1836, the yield differential between the United States and London was small on average: .0013, only13 basis points. Yields were slightly lower in London than New York, consistent with the general idea that credit markets were deeper and interest rates lower in London, as well as with higher transaction costs of marketing American bonds in Britain. ${ }^{23}$ The average difference for Pennsylvania bonds was .003, for New York bonds .001, and for Ohio bonds -.0008 (on average Ohio bonds had slightly higher yields in London than in New York). As we saw earlier, these markets were well integrated.

Bond yields began rising in 1836, a full percentage point in the U.S. and almost 3/4 of a percentage point in London. Credit markets tightened everywhere in 1836 (Figure 1). Yields continued to rise through early 1837 in both London and the U.S., but more quickly in the U.S.. When the Panic broke out in May, however, yields moved in opposite directions in the U.S. and 
in Britain. In the third quarter of 1837, yields on New York bonds in London rose to 5.46 percent, while in the U.S. they fell to 3.94 percent (Table 5, columns 1 and 2). For the remainder of 1837 , all of 1838 , and the first three quarters of 1839 , it was more expensive for state governments to borrow in London than in New York or Philadelphia. Both 1838 and 1839 were years of heavy new state borrowing and there were frequent quotations in every market. In the aftermath of the Panic of 1837, credit markets for American state bonds were significantly tighter in London than in the United States.

The summer of 1839 was a turning point for the transportation boom in the northwest. The Morris Bank defaulted on its July installment to Indiana. As the year progressed it became clear that Indiana, Michigan, and Illinois were in serious trouble, a concern immediately reflected in yields on their bonds. Indiana bond yields in London rose from 5.92 percent in June, to 8.76 percent in November (Table 7, there are no quotes in between those dates in London, and there are no quotes for Indiana bonds in New York before 1840). ${ }^{24}$ Illinois bonds in New York went from a yield of 4.9 percent in July to 11.1 percent in November and 13 percent in December, while in London Illinois bonds went from a yield of 5.98 percent in July to 7.32 percent in January. Financial markets acknowledged that it was primarily the western states whose credit was threatened. Yields on eastern state bonds rose in 1839, but not nearly to the extent of yields on western bonds.

The BUSP once again suspended specie payments in October, 1839. This crisis hit U.S. markets for state bonds much harder than it hit the London market. In the third quarter of 1839 , the average yield on New York bonds was 5.19 percent in the U.S. and 5.04 percent in London. In the fourth quarter of 1839, the average yield on New York bonds was 7.76 percent in the U.S. and 6.19 in London. For the remainder of 1840 and 1841, average yields stayed higher in the U.S. than in London. The New York-London differential on New York bonds was over 0.5 percent throughout both years (Figure 5); for Ohio bonds, between 0.1 and 0.5 percent (Figure 
7); and for Illinois bonds over a full percentage point or more. Unlike the aftermath of the Panic of 1837, when markets for state bonds were tighter in London than they were in the United States, after the Crisis of 1839 markets for state bonds were distinctly tighter in the United States than in London.

We are now in a position to examine the origin of the shock to bond markets. Figures 5 and 7, the difference in New York and Ohio bond yields in the United States and London, show distinct spikes in the U.S.-London yield differentials at the end of $1839{ }^{25}$ This is the first spike in the bond differentials, small compared to what was to come in 1842 , but telling nonetheless. Up to 1839 , markets in New York, Philadelphia, and London shared the same information. In the fall of 1839, news hit the markets in America first. Bond prices dropped and yields rose in New York about two months before yields rose in London. Unlike 1837, when credit conditions tightened on both sides of the Atlantic and the news about the Panic of 1837 did not originate in either country, in 1839 the event that shocked bond markets clearly originated in the United States. $^{26}$

Temin suggested that American states were forced to abandon their internal improvement projects after the Crisis of 1839 because British capital dried up. His conjecture finds no support in the financial market data. After the Panic of 1837, it was consistently more expensive for states to borrow in London than in New York and Philadelphia. After the Crisis of 1839, it was consistently cheaper for states to borrow in London than in New York and Philadelphia, and this was true for all states. States, of course, found it harder to borrow everywhere in 1840 and 1841 , when yields on New York and Ohio bonds reached 7 percent, and yields on Illinois and Indiana bonds went to 8 percent and higher. But it was not relatively harder to borrow in London than it was in America. The idea that the depression that developed in the United States after October 1839 was due to the tightening of British capital markets is not supported by the bond yields. Although yields were more favorable to borrowers in London than in the U.S., states 
found it difficult to borrow in both the U.S. and London in 1840. States with par restrictions on their bonds could not market any bonds at prevailing rates. But they could sell bonds if they were willing to pay market rates. For example, Illinois had issued bonds to state contractors in lieu of cash payments, bonds the contractors had accepted at par. When state agents went to London in July of 1840, they took both new state bonds with par restrictions and contractor bonds. The contractor bonds were identical to the new bonds in every respect except the par restriction. 'None of the state bonds were sold, but an agreement was made to sell $\$ 1,000,000$ of the contractors' bonds to Magniac, Smith and Company of London at a rate of eighty-three. ${ }^{27}$ Ohio continued to borrow through 1843, authorizing new bond issues at less than par. The state was able to sell $\$ 400,000$ in bonds in July of 1840 to Barings at a price of 95 and an additional $\$ 400,000$ in bonds in May of 1842 at 'the distressingly low price of 60.' ${ }^{28}$ States could borrow, but not if they insisted on selling 5 or 6 percent bonds at par.

\section{The Collapse of 1842:}

Financial historians have paid little attention to the Collapse of 1842, but big things were happening that year in the market for state bonds. The collapse in state debt markets is traditionally attributed to state defaults (Table 2). The timing of defaults and bond yield movements shows that the onset of the default crisis cannot account entirely for the collapse of state debt markets. In 1841, Indiana and Florida defaulted in January, Mississippi in March, and Michigan and Arkansas in July. Yet yields on New York and Ohio bonds were not noticeably higher in the first quarter of 1841 than they had been for most of 1840. Although yields rose in the second and third quarter of 1841, the increase was small compared to the jump that occurred in the fourth quarter of 1841 and the first quarter of 1842. Something happened in the winter of 1842 that shook American credit markets. And it wasn't just the defaulting states that experienced a crisis in the winter of 1842: yields for issues of Ohio and New York bonds, states that avoided default, spiked in the U.S. market as well. 
The crisis in the winter of 1842 originated in the United States. The news hit American markets first, American markets quickly increased the risk premium placed on American state bonds, and London did not digest the news from American markets for several months. In the first quarter of 1842, the yield on New York bonds was 9.89 percent in New York and 6.62 percent in London; on Ohio bonds, 12.78 percent in New York and 8.86 percent in London; on Illinois bonds, 43.74 percent in New York and 26.78 percent in London. Figures 10, 11, and 12 focus on bond yield differences between January 1841 and December 1843 (these figures expand the time scale of the data in Figures 5, 7, and 9). As the default crisis unfolded in 1841, yields in New York stayed close to yields in London. But in January of 1842, yields moved sharply higher in the United States, peaking in late March. Yields on New York, Ohio, and Pennsylvania bonds were at least 8 percentage points higher in New York and Philadelphia than the contemporaneous prices in London.

The shock was not transitory. Bond yields remained higher in both markets through 1842. But the disjunction between bond yields in the United States and in London was transitory. By April 17, 1842, New York, Ohio, and Pennsylvania bonds were again trading for the same prices in London, New York, and Philadelphia. ${ }^{29}$ For the second quarter as a whole, yields were only 0.0028 (28 basis points) higher in New York than in London. Markets were well integrated, but the shock hit America first and, given the time it took information to propagate to Britain, London did not react for over a month.

What happened? Pennsylvania was the locus of the crisis. As early as 1839 , Pennsylvania was in deep financial trouble, but BUSP loans masked the state's weakness until the state was forced back into regular credit markets. After the BUSP failed in February 1841, the yields on Pennsylvania bonds in Philadelphia began rising: from 5.76 percent in the last quarter of 1840 , to 8.05 percent in the first quarter of $1841,8.43$ percent in the third quarter, 11.42 percent in the fourth quarter, and 17.99 percent in the first quarter of 1842 . 
State chartered banks were not at liberty to refuse loans to the state government that chartered them. Throughout 1841, Pennsylvania leaned on its banks. In November of 1841, Pennsylvania announced that it would require a loan from all banks in the state equal to 5 percent of their capital. The news that hit American markets in December 1841 and January 1842, as the state began gathering loans from its banks, was that Pennsylvania was actually carrying out its threat to make the banks sustain the state credit through forced loans. In February of 1842 , the state precipitated a banking panic in Philadelphia, when it attempted to withdraw funds from the Bank of Philadelphia necessary to cover the interest payments due that month. ${ }^{30}$ At that point, the state had not yet decided whether it would rescue the state credit by extorting more money from state chartered banks. When Pennsylvania made it clear that it would not force more loans from state banks in April of 1842, the crisis was over. As a result of the state's decision not to press its banks it became inevitable that Pennsylvania would default on its August 1842 interest payment, and Pennsylvania bond yields in London and Philadelphia accordingly rose steadily until the third quarter. Yields on Pennsylvania bonds would not fall back below 10 percent until April of 1844, and the state resumed interest payments in February 1845.

Conditions were similar in New York, where the state pressed state chartered banks to purchase state bonds. New York bank holdings of state 'stock' rose from nothing in 1839 to almost $\$ 7$ million in 1842. The New York state legislature met in emergency session in March to consider how to deal with the impending state default. It responded with the 'Stop and Tax' law of 1842, stopping borrowing, stopping construction on canals, and reinstituting the state property tax. These measures ended the crisis in New York bonds.

Ohio relied heavily on its banks for funds. Ohio raised $\$ 900,000$ in $1842, \$ 500,000$ from state chartered banks and the $\$ 400,000$ borrowed through Barings in London. ${ }^{31}$ As long as Ohio continued its internal improvement projects, financial markets continued to purchase Ohio bonds 
at prices significantly below par. Yields on Ohio bonds in New York and London remained over 10 percent until the second quarter of 1843 . Because Ohio could pressure its banks in a way that it could not pressure financial markets, as interest rates rose the state issued more bonds to its banks and fewer directly to financial markets. When it did place new bonds, it placed them in London, not in New York.

Rising yields on Ohio and New York bonds in late 1841 were not a response to the default crisis in Mississippi, Florida, Arkansas, Indiana, and Michigan. The Governor of Mississippi announced that he supported repudiation in early 1841 . When Mississippi and Florida repudiated their bonds by legislative act in February of 1842 this was old news. The news in the winter of 1842 was the threat that New York, Ohio, and Pennsylvania would cannibalize their banks to keep state finances afloat. Pennsylvania's announcement of the forced loan program in November 1841 gave concrete expression to the threat. Throughout the winter of 1842 it was not clear what additional steps states would take to deal with the crisis. Fundamental uncertainty drove bond prices down, bond yields up, and brought an end to any hopes that states would be able to raise large amounts of capital at reasonable rates to continue their internal improvement projects. News of the threat and an appreciation of its magnitude took several months to reach Britain.

The Collapse of 1842 was not brought on by tight credit markets in Britain after the Crisis of 1839 , but by a political crisis in the United States in the winter of 1842 . Even so, financial markets sorted themselves out quickly. Interest rates on all state debts would be higher in April of 1842 than in October of 1841, but markets in London and New York would pay the same yields on Ohio and New York bonds.

\section{Conclusions}

In 1841, Nicholas Biddle argued that European conditions played an important role in the 
economic crisis in 1839, and one need go no further than Leland Jenks's Migration of British Capital or Bray Hammond's Banks and Politics in America to see how much economic historians have laid the blame for the depression of 1839 to 1842 at the feet of international conditions. Peter Temin made no bones about the centrality of British credit in bringing on the Crisis of 1839 and the collapse of state internal improvement projects: 'The state projects initiated in the late 1830 s had been started in the expectation of external [British] financing.... Unfortunately, the new inflow of foreign capital did not continue [in 1839]... and the manifold projects of the states were abandoned.' Three clear findings of this paper challenge this traditional interpretation.

First, the conditions that brought on the Panic of 1837 could not have anything to do with the crisis in American state debts after 1839. The majority of state debt outstanding in 1841 was incurred after Panic, not before. The vast majority of debt in New York, Ohio, Massachusetts, Indiana, Illinois, Michigan, Arkansas, Maryland, and Mississippi involved in the default crisis was authorized in 1837 or later and issued long after the Panic of 1837 was over. New York, Ohio, and Pennsylvania continued to issue and market bonds in 1840 and 1841.

Second, before 1837 state bonds had marketed for a slightly higher prices (lower yields) in London than New York and Philadelphia. After the Panic of 1837, London markets for American state bonds became noticeably tighter than American markets, during the three years of the heaviest borrowing: 1837,1838 , and 1839. Yet, when the BUSP suspended payments in October 1839, the economic crisis set in, and bond yields rose sharply in both countries, yields in London became significantly lower than yields in the U.S.. States such as Ohio and Illinois could borrow at lower cost in London than in New York, and so they borrowed in London. 
There is no evidence that British credit markets dried up relative to American markets after 1839. States had more trouble borrowing in both markets, of course, and states were forced out of the market entirely if they insisted on borrowing at par. The collapse of state transportation projects in Indiana, Illinois, and Michigan in 1839 had nothing to do with credit markets in London, and everything to do with the defalcation of American banks such as the Morris Canal and Banking Company, which failed to pay states for bonds they had already accepted and on which the states were liable to pay interest immediately.

Third, the movement of bond yields during the Crisis of 1839 and the Collapse of 1842 indisputably show that the shocks to financial markets originated in the United States and spread to London, not the other way around. As the economic crisis deepened in 1840 and 1841, New York, Ohio, and Pennsylvania put greater pressure on their own state chartered banks to buy state bonds. This was not because the states could not sell bonds in London, but because the yields on those bonds in London, New York, and Philadelphia were justifiably rising. Pennsylvania's forced loan policy, beginning in November of 1841, tipped American markets into crisis.

Our focus on the market for state bonds in London and the United States precludes us from drawing similar conclusions about the course of the overall economies of the United States and Britain in these years. That would require a great deal more time and space. But we hope we have given more weight to Matthews's conclusion that 'enough has been said in the present chapter to indicate the powerful nature of forces making for instability from within the United States in this period.' 
Endnotes

1.Leland Jenks, Migration of British Capital, pp. 90-95, and Bray Hammond, Banks and Politics in America, pp. 500-513, stress the importance of British capital markets and international forces in bringing on the crises. Nicholas Biddle, in a letter to John Clayton dated April 9, 1841, in which he defended his actions at the Bank of the United States and attempted to explain why the bank had failed after his departure as President, Biddle wrote: 'I have just stated that the winter of 1838-'39 was a season of great abundance and ease in moneyed concerns, both in England and this country; but England was soon after startled by the discovery that the grain crop was deficient, and a demand arose for specie to export for grain, combined with some continental loans, that changed the whole surface of affairs. The Bank of England itself, after borrowing ten millions of dollars from the Bank of France, was still so much drained for coin that it was forced into very severe restrictive measures, which raised the interest of money to twice or three times its usual rate. The most injurious effect was on the stocks of this country [the U.S.], which were no longer convertible in England, accept at great sacrifices. These causes immediately reacted on this country, producing the usual effects of embarrassment in the community and alarm among the banks.' In House Document \#226, $29^{\text {th }}$ Congress, First Session, p. 488.

2. Matthews, Trade-Cycle, p. 69.

3. See, for example, Scheiber's Ohio Canal Era estimates of foreign holders of Ohio bonds, Ratchford's American State Debts, and McGrane Foreign Bondholders.

4.The first quote is from Temin, The Jacksonian Economy, p. 151 and the second quote from p. 153.

5.Temin, Jacksonian Economy, p, 157, citing Gallman's unpublished estimates of annual GNP, argues that the crises in the United States had a much larger effect on prices than on output. Also see Temin, 'The Anglo-American Business Cycle' where he shows that the American 
economy experienced greater price fluctuations over these business cycles, while the British economy experienced greater fluctuations in real economic activity.

6.The quote is from Clapham, Bank of England, p. 153. See Hidy, House of Baring, as well, pp. 205-24.

7. Whether the Panic of 1837 in the United States was caused primarily by international or domestic forces is a question with a long pedigree. See Rousseau, 'Jacksonian Monetary Policy;' Temin Jacksonian Economy and 'The Anglo-American Business Cycle, 1820-60;' and Timberlake, 'The Specie Circular and the Distribution of the Surplus' and 'The Specie Standard and Central Banking in the United States Before 1860;' and Macesich 'Sources of Monetary Disturbances in the United States, 1834-1845.' Heavy land sales in 1835 and 1836 swelled federal revenues just as the federal government had paid off the national debt. The fiscal surplus grew rapidly, and in 1836 plans were made to distribute $\$ 36$ million to the states in four quarterly installments in 1837. See Bourne Surplus Revenue Act.

8.Table 1 reports debt outstanding on September 1, 1841. The debt is listed by the year it was authorized, since it is difficult to determine when individual bonds were sold. The bottom three rows of the table report the amount outstanding, the total debt authorized, and the total amount ever issued (some debt had been retired by 1841).

9.The installments were fixed in time and amount. The states were not paid when the banks sold the bonds, these were not consignment or commission sales.

10.For detailed consideration of land values and property tax revenues in Indiana in these years see Wallis 'The Property Tax.' Only Illinois continued to borrow, at extremely high rates, in an attempt to maintain its credit and to continue construction. The state was not successful at either goal. Heavy borrowing in 1840 saddled the state with debts the state would struggle to pay into the 1850 s, without any significant physical accomplishments. The best overall history of state investments in transportation is Goodrich Government Promotion. Goodrich has recently been 
supplemented by Larson Internal Improvements. Details about Indiana can be found in Fatout Indiana Canals and Illinois in Krenkel Illinois Internal Improvements.

11.By 1839 the BUSP had an extensive operation in Britain headed by Samuel Jaudon, so attributing the causes of the bank's demise to domestic and international forces is complicated. But the causes of the suspension in October of 1839 were a run on the Philadelphia bank by banks in New York and Boston. Hammond, 'Chestnut Raid on Wall Street;' Smith, Economic Aspects.

12. The data underlying the figures is discussed in the next section.

13.Their database will soon be available at ICPSR: 'Price Quotations in Early U.S. Securities Markets.'

14.Price quotations were typically reported weekly, recorded by the date of the newspaper issue. Prices were not quoted on the same day in each market, and in several cases quotes were provided for more than one day in each week. Our analysis focuses on weekly quotations, except where noted. The Boston market data are not available from June 1841 to September 1843, and the New York series on Massachusetts bonds is incomplete. The Baltimore market data include complete data on generic 'Maryland 5s' and 'Maryland 6s' without maturity dates, and the prices for specific Maryland bonds is spotty.

15.The restrictions states placed on intermediaries are difficult to track. When the state appointed a state official to sell bonds in New York or London, the official was clearly bound by the par restriction. When states used investment bankers the situation was less clear. One would think that once investment bankers had paid for the bonds, they would no longer be bound by the par restriction. Investment bankers who took consignment of bonds would be bound by the par restriction. Yet, for example, Nicholas Biddle and the BUSP took almost all of Mississippi's 1838 issue of $\$ 5$ million, paid for it on credit over the following year, and then failed to sell the bonds in London. The BUSP used \$3,008,000 in Mississippi bonds as collateral for European 
loans, Smith, Economic Aspects, p. 218. Altogether, the BUSP used almost $\$ 13,000,000$ in state bonds as collateral for loans in the fall of 1839 and winter of 1840. It is not clear why Biddle didn't sell the bonds, unless, perhaps, he could not because of concerns about par restrictions. 16.For simplicity, we assumed that all bonds matured on January 1 and paid a single annual premium. Bond yields for the last two years proceeding maturity were dropped from the calculated averages. Yields were calculated for bid and ask prices, and both bid and ask yields were included in the market averages. Unfortunately, the quotations for Maryland bonds did not include a maturity.

17.The ARCH estimator is more fully described in an appendix available from the authors. The appendix also explain the estimation technique used to account for missing observations. 18.This is the first step of an EM algorithm - a popular tool for finding maximum likelihood estimates in incomplete data problems. See Meng and Rubin 'Maximum Likelihood Estimation.'

19.The difference is the arithmetic difference in the average prices for the year or quarter. 20.The near equivalence of New York, Ohio, and Pennsylvania yields in 1836 is misleading, since there were only 4 observations on New York bond yields in New York that year. Most of the New York bonds were paid off in 1836.

21. Why the price difference was not arbitraged away is something of a mystery. It is possible that the quoted Philadelphia prices reflect prearranged transactions in new bond issues between the state and the BUSP. Bond holders in the secondary market were not able to sell bonds to BUSP at the low yields/high prices. The BUSP held a large stock of Pennsylvania bonds, but not the entire $\$ 30$ million issued up to 1839 . If this was the case, then the stability of the quoted price may not reflect the true price of Pennsylvania bonds on the open market. In either case, the use of the Pennsylvania bond yields for cross country comparisons is problematic. 
22.Details of the bank's demise can be found in Smith, Economic Aspects, Hammond, Banks and Politics in America, and Govan, Nicholas Biddle.

23.The idea that British credit markets were deeper than American goes back at least to Callender, 'Early Transportation and Banking Enterprises,' whose essay lays out the importance of British capital for American development and the role of American states in tapping foreign and domestic credit markets to support internal improvements.

24.This may be because the Indiana bonds sold on credit to the Morris Bank were sent to London, and from there to Amsterdam. The Morris Canal and Banking Company took the Indiana bonds it purchased on credit and used them to pay off the mortgage held on the canal by Dutch creditors. By the summer of 1839, the Morris Bank did not hold any Indiana bonds, it had already sold or hypothecated all of them. There is no published account of the incident that we are aware of. But the minutes of the Company's Board of Directors are available at the New Jersey State Archives, and the story can be tracked through them.

25.This is in the time interval when Pennsylvania bond prices are supported by the BUSP, so the yield differential between Philadelphia and London becomes more negative. This, however, is a function of the BUSP support.

26. There is no possibility that a positive shock hit the London markets in October of 1839. Equity prices in London were falling, not rising in the late 1839, see Gayer, Rostow, and Schwartz, Growth and Fluctuation.

27.Krenkel, Illinois Internal Improvement, p. 122.

28.Scheiber, Ohio Canals,pp. 140-158, quote from p. 152. At a price of 60, the yield on a 6 per cent bond was roughly 10 percent. Ohio did not include a par restriction in the legislation authorizing bond issues in 1836, so most Ohio bonds could be sold at any price. Ohio did have problems with price restrictions, however. One issue of bonds had been sold for less than the 
legislated minimum and at one point markets in New York believed, erroneously, that the state was about to default on bonds that had been sold in violation the legislated price.

29. Bond prices moved sharply upward in London that week, New York bonds went from yields of 6.38 percent to 8.05 percent and Ohio bonds from yields of 9.34 percent to 12.5 percent. At the same time, yields moved down in New York, bring yields in the two markets back into parity.

30.The funds Pennsylvania withdrew were the funds they had borrowed from other banks in the state. Pennsylvania did not default on its bonds until 1842, but they were several days late on an interest payment in February because of the banking crisis. The crisis in Pennsylvania and the state's interaction with its banks is described in Kettell 'Debts and Finances' and the Pennsylvania Report in House Document 226, $29^{\text {th }}$ Congress, First Session.

31. Scheiber, Ohio Canals, pp. 140-158. 'During the remainder of 1842, the fund board sustained installment payments on the three-year loans by issuing bonds to Ohio banks at prices of 70 to 75 [yields of roughly 8 percent]. In this manner, nearly $\$ 700,000$ of bonds were sold for cash payments of only $\$ 500,000$.' p. 152. As noted earlier, Ohio sold its bonds to Barings for a price of 60 . 


\section{References}

Bourne, Edward G. The History of the Surplus Revenue Act of 1837. Original published in 1885. Reprinted by Burt Franklin: New York, 1968.

Callender, Guy Stevens. 'The Early Transportation and Banking Enterprises of the States.' Quarterly Journal of Economics, vol. XVII, no. 1, 1902.

Clapham, John. The Bank of England. Cambridge: Cambridge University Press, 1945.

English, William B. 'Understanding the Costs of Sovereign Default: American State Debts in the 1840's.' American Economic Review, 86, March 1996, 259-75.

Fatout, Paul. Indiana Canals. West Lafayette, Indiana: Purdue University Studies, 1972.

Gayer, Arthur D., W.W. Rostow, and Anna Jacobson Schwartz. The Growth and Fluctuation of the British Economy, 1790-1850. Oxford: Clarendon Press, 1953.

Goodrich, Carter. Government Promotion of American Canals and Railroads. New York: Columbia University Press, 1960.

Govan, Thomas Payne. Nicholas Biddle. Chicago: University of Chicago Press, 1959. 
Hammond, Bray. Banks and Politics in America: From the Revolution to the Civil War. Princeton: Princeton University Press, 1957.

Hammond, Bray. 'The Chestnut Raid on Wall Street, 1839.' Quarterly Journal of Economics, 61, 4, August 1947, 1-23.

Hidy, Ralph W. The House of Baring in American Trade and Finance. Cambridge: Harvard University Press, 1949.

Jenks, Leland Hamilton. The Migration of British Capital to 1875. New York: Knopf, 1938.

Kettell, Thomas Prentice. 'Debts and Finances of the States of the Union: With Reference to the General Condition and Character; Chapter IV, Middle States - Pennsylvania.' The Merchant Magazine, vol. XX, no III, (March, 1849), 256-68.

Krenkel, John H, Illinois Internal Improvements 1818-1848. Cedar Rapids: The Torch Press, 1958.

Larson, John Lauritz. Internal Improvements. University of North Carolina Press, 2001.

McGrane, Reginald C. Foreign Bondholders and American State Debts. New York: Macmillan Company, 1935. 
Macesich, George. 'Sources of Monetary Disturbances in the United States, 1834-1845.' Journal of Economic History, 20 3, September 1960, pp. 407-34.

Matthews, R.C.O. A Study in Trade-Cycle History. Cambridge: Cambridge University Press, 1954.

Meng, Xiao-Li and Donald Rubin, 'Maximum Likelihood Estimation via the ECM Algorithm: A General Framework.’ Biometrica, June 1993, pp. 267-98.

Officer, Lawrence H. "Integration in the American Foreign Exchange Market, 1791-1900." Journal of Economic History, Vol. 45, 3, September, 1985, 557-85.

Ratchford, B. U. American State Debts. Durham: Duke University Press, 1941.

Rousseau, Peter L. 'Jacksonian Monetary Policy, Specie Flows, and the Panic of 1837.' Journal of Economic History. 62 (2002) pp. 457-488.

Scheiber, Harry N. Ohio Canal Era: A Case Study of Government and the Economy, 1820-1861. Athens, Ohio: The Ohio State University Press, 1969.

Smith, Walter B. Economic Aspects of the Second Bank of the United States. Cambridge: Harvard University Press, 1953. 
Smith, Walter B. and Arthur Harrison Cole. Fluctuations in American Business, 1790-1860. Harvard University Press: Cambridge, 1935.

Sylla, Richard E., Wilson, Jack, and Wright, Robert. Price Quotations in Early U.S. Securities Markets. Database archived at ICPSR.

Temin, Peter. The Jacksonian Economy. New York: W. W. Norton and Company, 1969.

-----. 'The Anglo-American Business Cycle, 1820-60. ' The Economic History Review,

Timberlake, Richard H. 'The Specie Circular and the Distribution of the Surplus.' Journal of Political Economy, 68, 2, April 1960, 109-117.

-----. 'The Specie Standard and Central Banking in the United States Before 1860.' Journal of Economic History, 21, 3, Sept 1961, 318-341.

Wallis, John Joseph. 'The Property Tax as a Coordinating Device: Financing Indiana's Mammoth System of Internal Improvements.' Explorations in Economic History, July 2003. 
Table 1

Debt Outstanding on September 1, 1841

By Year of Authorization

Thousands of dollars

\begin{tabular}{|c|c|c|c|c|c|c|c|c|c|c|c|c|c|c|c|}
\hline & $\begin{array}{c}\text { Before } \\
1830\end{array}$ & 1830 & 1831 & 1832 & 1833 & 1834 & 1835 & 1836 & 1837 & 1838 & 1839 & 1840 & 1841 & \multicolumn{2}{|c|}{$\begin{array}{l}\text { State Percent } \\
\text { Totals } 1837-41\end{array}$} \\
\hline Illinois & 0 & 0 & 0 & 0 & 0 & 0 & 0 & 500 & 3,165 & 0 & 3,478 & 5,079 & 1,306 & 13,527 & $100 \%$ \\
\hline Indiana & 0 & 0 & 0 & 200 & 0 & 1,790 & 227 & 7,771 & 0 & 1,400 & 1,363 & 0 & 0 & 12,751 & $83 \%$ \\
\hline Michigan & 0 & 0 & 0 & 0 & 0 & 0 & 100 & 0 & 5,020 & 451 & 40 & 0 & 0 & 5,611 & $98 \%$ \\
\hline Alabama & 100 & 0 & 0 & 3,800 & 0 & 0 & 1,600 & 2,400 & 5,000 & 2,500 & 0 & 0 & 0 & 15,400 & $64 \%$ \\
\hline Florida & 0 & 0 & 0 & 0 & 3,000 & 0 & 900 & 0 & 0 & 0 & 100 & 0 & 0 & 4,000 & $3 \%$ \\
\hline Mississippi & 0 & 500 & 0 & 0 & 1,500 & 0 & 0 & 0 & 0 & 5,000 & 0 & 0 & 0 & 7,000 & $71 \%$ \\
\hline Arkansas & 0 & 0 & 0 & 0 & 0 & 0 & 0 & 146 & 2,530 & 0 & 0 & 0 & 0 & 2,676 & $100 \%$ \\
\hline Louisiana & 3,200 & 0 & 0 & 7,0001 & 12,000 & 0 & 0 & 0 & 600 & 0 & 1,185 & 0 & 0 & 23,985 & $7 \%$ \\
\hline Ohio & 3,800 & 600 & 0 & 100 & 0 & 0 & 0 & 170 & 550 & 1,710 & 3,476 & 149 & 369 & 10,924 & $57 \%$ \\
\hline Massachusetts & 0 & 0 & 0 & 0 & 0 & 0 & 0 & 0 & 1,900 & 2,200 & 1,644 & 0 & 225 & 5,969 & $100 \%$ \\
\hline New York & 1,250 & 0 & 0 & 5,066 & 93 & 0 & 0 & 2,000 & 250 & 5,088 & 50 & 7,784 & 216 & 21,797 & $71 \%$ \\
\hline Pennsylvania & 6,959 & 4,000 & 3,016 & 2,649 & 3,271 & 2,265 & 960 & 0 & 0 & 15 & 6,289 & 3,754 & 3,159 & 36,336 & $36 \%$ \\
\hline Maryland & 146 & 597 & 0 & 0 & 1,122 & 3,020 & 40 & 20 & 500 & 8,775 & 903 & 0 & 92 & 15,215 & $68 \%$ \\
\hline Maine & 0 & 0 & 0 & 0 & 0 & 0 & 0 & 0 & 2 & 267 & 507 & 825 & 133 & 1,735 & $100 \%$ \\
\hline Virginia & 1,631 & 16 & 140 & 1,155 & 299 & 826 & 714 & 15 & 573 & 959 & 2,364 & 18 & 34 & 8,744 & $45 \%$ \\
\hline South Carolina & 944 & 0 & 0 & 0 & 0 & 0 & 0 & 0 & 0 & 2,148 & 600 & 0 & 0 & 3,691 & $74 \%$ \\
\hline Georgia & 0 & 0 & 0 & 0 & 0 & 0 & 0 & 0 & 903 & 422 & 0 & 0 & 0 & 1,325 & $100 \%$ \\
\hline Kentucky & 0 & 0 & 0 & 0 & 0 & 0 & 200 & 190 & 0 & 1,250 & 33 & 1,413 & 0 & 3,086 & $94 \%$ \\
\hline Tennessee & 0 & 0 & 0 & 500 & 0 & 0 & 35 & 0 & 0 & 2,881 & 0 & 0 & 0 & 3,416 & $84 \%$ \\
\hline Missouri & 0 & 0 & 0 & 0 & 0 & 0 & 0 & 0 & 432 & 0 & 145 & 0 & 265 & 842 & $100 \%$ \\
\hline
\end{tabular}


Total $18,029 \quad 5,713 \quad 3,15620,47021,285 \quad 7,901 \quad 4,775 \quad 13,212 \quad 21,425 \quad 35,06622,177 \quad 19,023 \quad 5,798 \quad 198,030$ $52 \%$

Outstanding

Total Authorized 20,739 5,716 3,156 20,471 21,350 7,909 7,220 18,589 21,609 41,617 26,795 27,377 12,170

Total Ever Issued20,741 $\quad 5,713 \quad 3,15620,47021,285 \quad 7,901 \quad 4,775$ 13,556 21,587 37,746 20,764 19,811 5,798 
Table 2

Default, Resumption, and Repudiation Dates

$\begin{array}{llrr} & & & \text { Resumed } \\ \text { State } & \text { Date } & \text { or } & \\ & & \text { Repudiated } & \text { Date } \\ \text { Indiana } & \text { January } 1841^{*} & \text { Resumed } & \text { July } 1847 \\ \text { Florida } & \text { January } 1841 & \text { Repudiated } & \text { February } 1842 \\ \text { Mississippi } & \text { March } 1841 & \text { Repudiated } & \text { February } 1842 \\ \text { Arkansas } & \text { July } 1841 & \text { Resumed } & \text { July } 1869 \\ & & \text { Repudiated } & \text { July } 1884 \text {, Holford } \\ & & & \text { Bonds } \\ \text { Michigan } & \text { July } 1841 & \text { Resumed } & \text { January } 1846 \\ & & \text { Repudiated } & \text { Part paid bonds, July } \\ & & \text { Partially } & 1849 \\ \text { Illinois } & \text { January } 1842 & \text { Resumed } & \text { July } 1846 \\ \text { Maryland } & \text { January } 1842 & \text { Resumed } & \text { July } 1848 \\ \text { Pennsylvania } & \text { August } 1842 & \text { Resumed } & \text { February } 1845 \\ \text { Louisiana } & \text { February } 1843 & \text { Resumed } & 1844 \\ & & \text { Repudiated } & ? ?\end{array}$




\begin{tabular}{|c|c|c|c|}
\hline \multirow[b]{2}{*}{ Parameter } & \multicolumn{2}{|c|}{$\mathrm{Y}=$ Observed and interpolated data } & \multirow{2}{*}{$\begin{array}{c}Y=\text { Only observed data } \\
\text { (Monthly) }\end{array}$} \\
\hline & Weekly & Monthly & \\
\hline$a_{1}$ & $\begin{array}{c}.051 \\
(1400.7)^{* *}\end{array}$ & $\begin{array}{c}.039 \\
(74.2)^{* *}\end{array}$ & .039 \\
\hline$a_{2}$ & $\begin{array}{c}.047 \\
(1648.4)^{* *}\end{array}$ & $\begin{array}{c}.039 \\
(68.5)^{* *}\end{array}$ & .04 \\
\hline$a_{11}$ & $\begin{array}{c}.000 \\
(7.26)^{* *}\end{array}$ & $\begin{array}{c}.000 \\
(8.35)^{* *}\end{array}$ & .001 \\
\hline $\mathrm{b}_{11}$ & $\begin{array}{c}1.01 \\
(3.12)^{* *}\end{array}$ & $\begin{array}{c}.86 \\
(5.53)^{* *}\end{array}$ & .70 \\
\hline$a_{21}$ & $\begin{array}{c}.000 \\
(4.80)^{* *}\end{array}$ & $\begin{array}{c}.000 \\
(6.54)^{* *}\end{array}$ & .001 \\
\hline$b_{21}$ & $\begin{array}{c}1.01 \\
(3.11)^{* *}\end{array}$ & $\begin{array}{c}.65 \\
(4.41)^{* *}\end{array}$ & .68 \\
\hline$a_{22}$ & $\begin{array}{c}.000 \\
(10.81)^{* *}\end{array}$ & $\begin{array}{c}.000 \\
(13.19)^{* *}\end{array}$ & .001 \\
\hline $\mathrm{b}_{22}$ & $\begin{array}{c}1.01 \\
(3.12)^{* *}\end{array}$ & $\begin{array}{c}.85 \\
(5.83)^{* *}\end{array}$ & .68 \\
\hline $\begin{array}{l}\text { Number of } \\
\text { Observations }\end{array}$ & 1230 & 366 & 289 \\
\hline Time Period & & $1829-1843$ & \\
\hline \multicolumn{4}{|c|}{$\begin{array}{l}\text { Technical Note: } \\
\text { (1) 1: London market, 2: American market } \\
\text { (2) The first dependent variable is the average YTM of NY, PA and OH bonds in London. The second } \\
\text { dependent variable is the average YTM of NY and OH bonds in NYC and PA in Philadelphia. }\end{array}$} \\
\hline
\end{tabular}


Table 4. Stock market integration test (Multivariate ARCH with 2 equations)

\begin{tabular}{|c|c|c|c|}
\hline \multirow[b]{2}{*}{ Parameter } & \multicolumn{2}{|c|}{ Weekly data } & \multirow{2}{*}{$\begin{array}{c}\text { Monthly data } \\
\begin{array}{c}\mathrm{Y}=\text { Capital Gain } \\
=\log \left(\mathrm{p}_{\mathrm{t}}\right)-\log \left(\mathrm{p}_{\mathrm{t}-1}\right)\end{array}\end{array}$} \\
\hline & $\begin{array}{c}Y=\log \text { of Stock Price } \\
=\log \left(p_{t}\right)\end{array}$ & $\begin{array}{l}Y=\text { Capital Gain } \\
=\log \left(p_{t}\right)-\log \left(p_{t-1}\right)\end{array}$ & \\
\hline$a_{1}$ & $\begin{array}{c}4.72 \\
(6078.15)^{* *}\end{array}$ & $\begin{array}{l}-.00 \\
(-.5)\end{array}$ & $\begin{array}{l}-.00 \\
(-.0)\end{array}$ \\
\hline$a_{2}$ & $\begin{array}{c}4.60 \\
(4585.44)^{* *}\end{array}$ & $\begin{array}{l}-.00 \\
(-.1)\end{array}$ & $\begin{array}{l}-.00 \\
(-.7)\end{array}$ \\
\hline$a_{11}$ & $\begin{array}{c}.001 \\
(22.96)^{* *}\end{array}$ & $\begin{array}{c}.00 \\
(40.7)^{* *}\end{array}$ & $\begin{array}{c}.00 \\
(10.4)^{* *}\end{array}$ \\
\hline$b_{11}$ & $\begin{array}{c}.95 \\
(6.88)^{* *}\end{array}$ & $\begin{array}{c}.47 \\
(9.5)^{* *}\end{array}$ & $\begin{array}{c}.62 \\
(5.5)^{* *}\end{array}$ \\
\hline$a_{21}$ & $\begin{array}{l}-.000 \\
(-.21)\end{array}$ & $\begin{array}{l}-.00 \\
(-.1)\end{array}$ & $\begin{array}{l}.00 \\
(.1)\end{array}$ \\
\hline $\mathrm{b}_{21}$ & $\begin{array}{c}.94 \\
(6.69)^{* *}\end{array}$ & $\begin{array}{c}-.13 \\
(-1.6)\end{array}$ & $\begin{array}{l}.11 \\
(.6)\end{array}$ \\
\hline$a_{22}$ & $\begin{array}{c}.000 \\
(10.5)^{* *}\end{array}$ & $\begin{array}{c}.00 \\
(52.2)^{* *}\end{array}$ & $\begin{array}{c}.00 \\
(11.9)^{* *}\end{array}$ \\
\hline$b_{22}$ & $\begin{array}{c}1.03 \\
(7.04)^{* *}\end{array}$ & $\begin{array}{c}.31 \\
(6.1)^{* *}\end{array}$ & $\begin{array}{c}.49 \\
(2.9)^{* *}\end{array}$ \\
\hline $\begin{array}{l}\text { Number of } \\
\text { Obs }\end{array}$ & & & 177 \\
\hline $\begin{array}{l}\text { Time } \\
\text { Period }\end{array}$ & & $1821-1836$ & \\
\hline \multicolumn{4}{|c|}{$\begin{array}{l}\text { Technical Note: } \\
\text { (1) 1: American market (Baltimore, Boston, New York and Philadelphia), 2: London market } \\
\text { (2) The average price in London is indexed by the average of the first years stock prices, because the } \\
\text { stock prices denoted in sterling and stayed around 25, where American prices stayed around } 100 .\end{array}$} \\
\hline
\end{tabular}


Table 5

Bond Yields in the United States and London

New York and Ohio Bonds

\begin{tabular}{|c|c|c|c|c|c|}
\hline & & NY & & & Ohio \\
\hline NY & NY & US- & Ohio & Ohio & US- \\
\hline London & US & Difference & London & US & Diffe \\
\hline
\end{tabular}

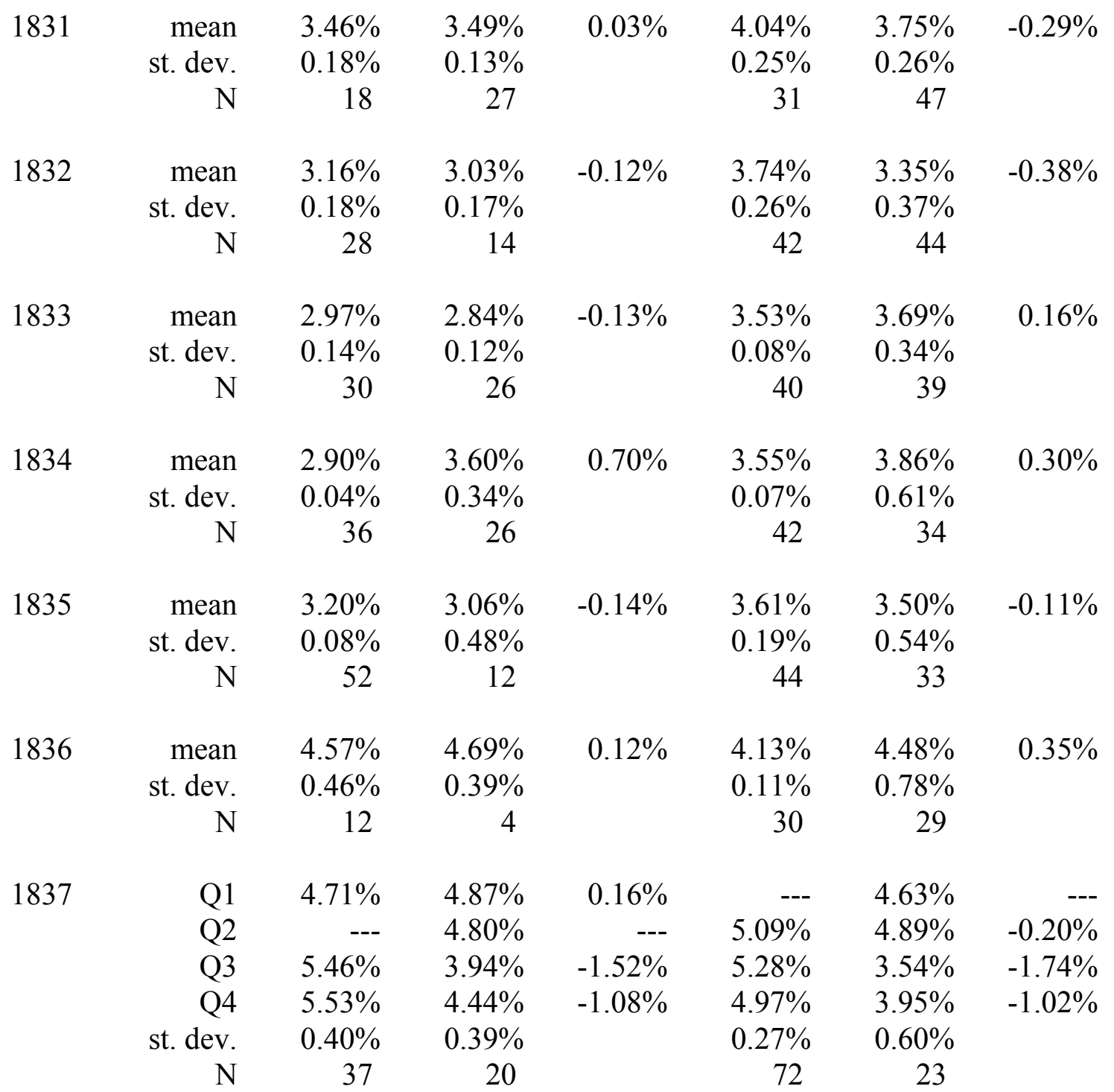




\begin{tabular}{|c|c|c|c|c|c|c|c|}
\hline \multirow[t]{6}{*}{1838} & Q1 & $5.03 \%$ & $4.34 \%$ & $-0.69 \%$ & $5.02 \%$ & $4.34 \%$ & $-0.68 \%$ \\
\hline & Q2 & $4.76 \%$ & $4.82 \%$ & $0.05 \%$ & $4.74 \%$ & $4.79 \%$ & $0.04 \%$ \\
\hline & Q3 & $4.66 \%$ & $4.83 \%$ & $0.17 \%$ & $4.91 \%$ & $3.76 \%$ & $-1.15 \%$ \\
\hline & Q4 & $4.69 \%$ & --- & --- & $4.81 \%$ & --- & --- \\
\hline & st. dev. & $0.19 \%$ & $0.25 \%$ & & $0.15 \%$ & $0.36 \%$ & \\
\hline & $\mathrm{N}$ & 55 & 12 & & 54 & 13 & \\
\hline \multirow[t]{6}{*}{1839} & Q1 & $4.96 \%$ & $5.00 \%$ & $0.04 \%$ & $5.22 \%$ & $4.51 \%$ & $-0.71 \%$ \\
\hline & Q2 & $4.95 \%$ & $4.94 \%$ & $-0.01 \%$ & $5.30 \%$ & $4.32 \%$ & $-0.98 \%$ \\
\hline & Q3 & $5.04 \%$ & $5.19 \%$ & $0.15 \%$ & $5.96 \%$ & $4.83 \%$ & $-1.12 \%$ \\
\hline & Q4 & $6.19 \%$ & $7.76 \%$ & $1.57 \%$ & $6.62 \%$ & $7.46 \%$ & $0.84 \%$ \\
\hline & st. dev. & $0.47 \%$ & $1.67 \%$ & & $0.61 \%$ & $1.69 \%$ & \\
\hline & $\mathrm{N}$ & 43 & 9 & & 44 & 11 & \\
\hline \multirow[t]{6}{*}{1840} & Q1 & $5.62 \%$ & $6.83 \%$ & $1.21 \%$ & $6.25 \%$ & $6.51 \%$ & $0.26 \%$ \\
\hline & Q2 & $5.55 \%$ & $6.23 \%$ & $0.68 \%$ & $6.01 \%$ & $6.30 \%$ & $0.29 \%$ \\
\hline & Q3 & $5.50 \%$ & $6.27 \%$ & $0.77 \%$ & $6.08 \%$ & $6.73 \%$ & $0.65 \%$ \\
\hline & Q4 & $5.70 \%$ & $6.22 \%$ & $0.52 \%$ & $6.12 \%$ & $6.26 \%$ & $0.14 \%$ \\
\hline & st. dev. & $5.60 \%$ & $6.41 \%$ & & $6.12 \%$ & $6.50 \%$ & \\
\hline & $\mathrm{N}$ & 52 & 40 & & 56 & 46 & \\
\hline \multirow[t]{6}{*}{1841} & Q1 & $5.87 \%$ & $6.89 \%$ & $1.02 \%$ & $6.30 \%$ & $6.45 \%$ & $0.15 \%$ \\
\hline & Q2 & $6.47 \%$ & $7.46 \%$ & $0.99 \%$ & $6.92 \%$ & $7.01 \%$ & $0.09 \%$ \\
\hline & Q3 & $6.53 \%$ & $7.16 \%$ & $0.62 \%$ & $7.01 \%$ & $6.20 \%$ & $-0.82 \%$ \\
\hline & Q4 & $6.75 \%$ & $7.99 \%$ & $1.24 \%$ & $6.88 \%$ & $7.31 \%$ & $0.43 \%$ \\
\hline & st. dev. & $0.34 \%$ & $0.90 \%$ & & $0.36 \%$ & $1.03 \%$ & \\
\hline & $\mathrm{N}$ & 94 & 85 & & 98 & 71 & \\
\hline \multirow[t]{6}{*}{1842} & Q1 & $6.62 \%$ & $9.89 \%$ & $3.27 \%$ & $8.86 \%$ & $12.78 \%$ & $3.93 \%$ \\
\hline & Q2 & $7.70 \%$ & $8.53 \%$ & $0.83 \%$ & $11.98 \%$ & $11.70 \%$ & $-0.28 \%$ \\
\hline & Q3 & $7.37 \%$ & $7.45 \%$ & $0.09 \%$ & $10.71 \%$ & $10.94 \%$ & $0.23 \%$ \\
\hline & Q4 & $7.32 \%$ & $7.72 \%$ & $0.40 \%$ & $9.78 \%$ & $11.86 \%$ & $2.08 \%$ \\
\hline & st. dev. & $0.50 \%$ & $1.67 \%$ & & $1.51 \%$ & $2.53 \%$ & \\
\hline & $\mathrm{N}$ & 46 & 51 & & 25 & 51 & \\
\hline \multirow[t]{6}{*}{1843} & Q1 & $6.64 \%$ & $6.53 \%$ & $-0.11 \%$ & $10.43 \%$ & $12.08 \%$ & $1.66 \%$ \\
\hline & Q2 & $5.85 \%$ & $5.80 \%$ & $-0.05 \%$ & $11.56 \%$ & $9.62 \%$ & $-1.93 \%$ \\
\hline & Q3 & $5.51 \%$ & $4.92 \%$ & $-0.59 \%$ & $8.77 \%$ & $7.23 \%$ & $-1.54 \%$ \\
\hline & Q4 & $4.86 \%$ & $4.74 \%$ & $-0.12 \%$ & $6.61 \%$ & $5.76 \%$ & $-0.85 \%$ \\
\hline & st. dev. & $0.74 \%$ & $0.81 \%$ & & $2.17 \%$ & $2.71 \%$ & \\
\hline & $\mathrm{N}$ & 41 & 50 & & 43 & 50 & \\
\hline
\end{tabular}


Table 6

Bond Yields in the United States and London

Pennsylvania Bonds, and New York/Ohio average yield

PA

PA PA US-London

London
US

Difference
NY \& Ohio NY \& Ohio

US Average Difference

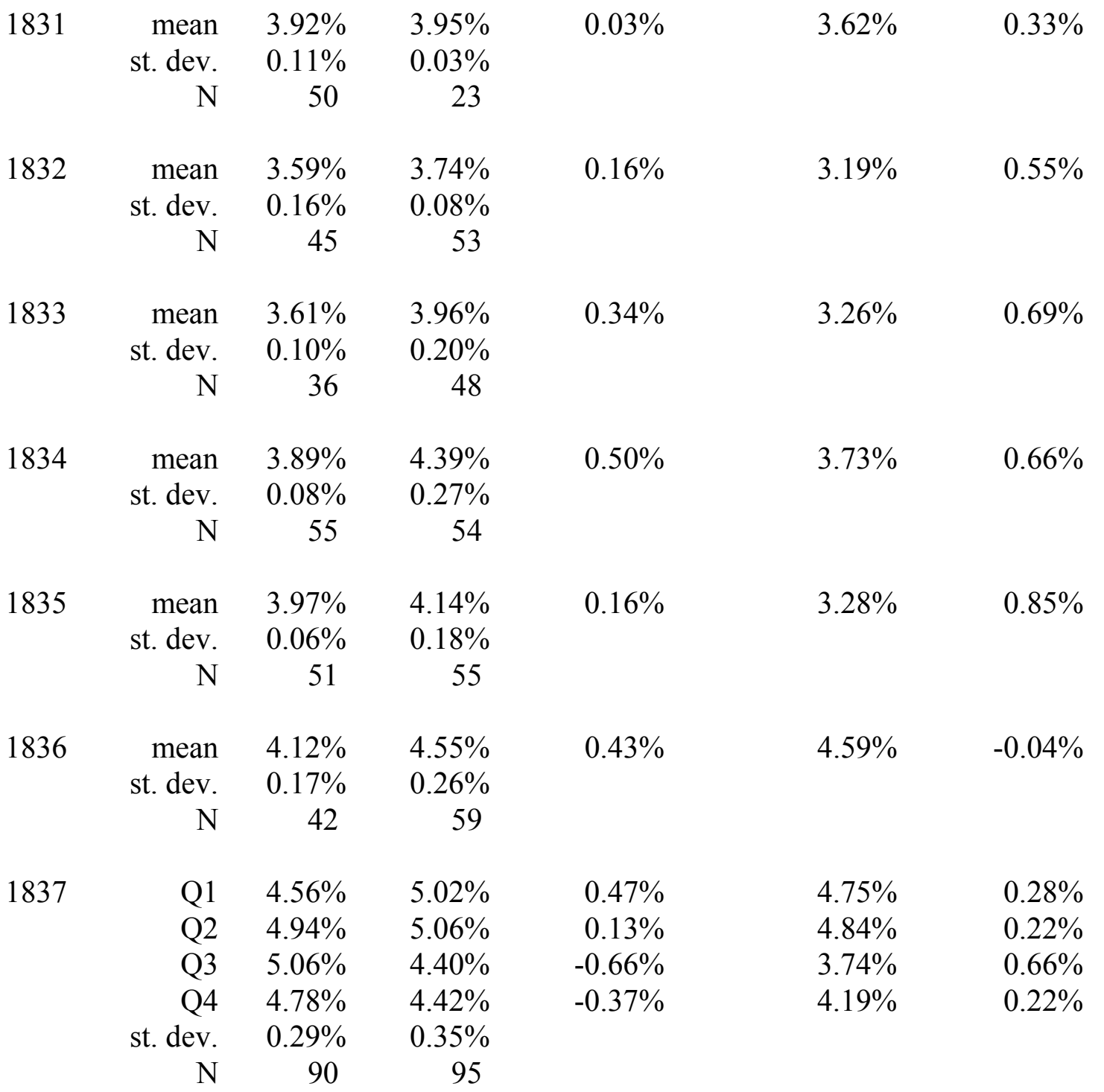




\begin{tabular}{|c|c|c|c|c|c|c|}
\hline \multirow[t]{6}{*}{1838} & Q1 & $4.87 \%$ & $4.56 \%$ & $-0.31 \%$ & $4.34 \%$ & $0.22 \%$ \\
\hline & Q2 & $4.86 \%$ & $4.55 \%$ & $-0.31 \%$ & $4.80 \%$ & $-0.25 \%$ \\
\hline & Q3 & $4.83 \%$ & $4.56 \%$ & $-0.27 \%$ & $4.29 \%$ & $0.27 \%$ \\
\hline & Q4 & $4.72 \%$ & $4.55 \%$ & $-0.17 \%$ & --- & --- \\
\hline & st. dev. & $0.07 \%$ & $0.02 \%$ & & & \\
\hline & $\mathrm{N}$ & 55 & 47 & & & \\
\hline \multirow[t]{6}{*}{1839} & Q1 & $4.96 \%$ & $4.55 \%$ & $-0.41 \%$ & $4.75 \%$ & $-0.20 \%$ \\
\hline & Q2 & $5.02 \%$ & $4.87 \%$ & $-0.14 \%$ & $4.63 \%$ & $0.24 \%$ \\
\hline & Q3 & $5.31 \%$ & $5.38 \%$ & $0.07 \%$ & $5.01 \%$ & $0.37 \%$ \\
\hline & Q4 & $6.91 \%$ & $6.14 \%$ & $-0.77 \%$ & $7.61 \%$ & $-1.47 \%$ \\
\hline & st. dev. & $0.62 \%$ & $0.58 \%$ & & & \\
\hline & $\mathrm{N}$ & 42 & 40 & & & \\
\hline \multirow[t]{6}{*}{1840} & Q1 & $6.73 \%$ & $5.87 \%$ & $-0.86 \%$ & $6.67 \%$ & $-0.79 \%$ \\
\hline & Q2 & $6.99 \%$ & $5.96 \%$ & $-1.04 \%$ & $6.27 \%$ & $-0.31 \%$ \\
\hline & Q3 & $6.30 \%$ & $5.42 \%$ & $-0.87 \%$ & $6.50 \%$ & $-1.07 \%$ \\
\hline & Q4 & $6.03 \%$ & $5.80 \%$ & $-0.23 \%$ & $6.24 \%$ & $-0.44 \%$ \\
\hline & st. dev. & $6.45 \%$ & $5.76 \%$ & & & \\
\hline & $\mathrm{N}$ & 58 & 56 & & & \\
\hline \multirow[t]{6}{*}{1841} & Q1 & $5.78 \%$ & $8.05 \%$ & $2.27 \%$ & $6.67 \%$ & $1.38 \%$ \\
\hline & Q2 & --- & $8.34 \%$ & $8.34 \%$ & $7.23 \%$ & $1.11 \%$ \\
\hline & Q3 & --- & $8.43 \%$ & $8.43 \%$ & $6.68 \%$ & $1.75 \%$ \\
\hline & Q4 & --- & $11.42 \%$ & $11.42 \%$ & $7.65 \%$ & $3.77 \%$ \\
\hline & st. dev. & $0.15 \%$ & $1.90 \%$ & & & \\
\hline & $\mathrm{N}$ & 22 & 84 & & & \\
\hline \multirow[t]{6}{*}{1842} & Q1 & $14.87 \%$ & $17.99 \%$ & $3.12 \%$ & $11.34 \%$ & $6.65 \%$ \\
\hline & Q2 & $15.09 \%$ & $21.86 \%$ & $6.77 \%$ & $10.12 \%$ & $11.75 \%$ \\
\hline & Q3 & $22.72 \%$ & $23.55 \%$ & $0.83 \%$ & $9.20 \%$ & $14.36 \%$ \\
\hline & Q4 & $13.98 \%$ & $18.85 \%$ & $4.88 \%$ & $9.79 \%$ & $9.07 \%$ \\
\hline & st. dev. & $3.51 \%$ & $2.99 \%$ & & & \\
\hline & $\mathrm{N}$ & 27 & 42 & & & \\
\hline \multirow[t]{6}{*}{1843} & Q1 & $15.89 \%$ & $21.02 \%$ & $5.13 \%$ & $9.31 \%$ & $11.71 \%$ \\
\hline & Q2 & $19.26 \%$ & $19.20 \%$ & $-0.06 \%$ & $7.71 \%$ & $11.49 \%$ \\
\hline & Q3 & $16.21 \%$ & $15.68 \%$ & $-0.53 \%$ & $6.08 \%$ & $9.61 \%$ \\
\hline & Q4 & $10.91 \%$ & $12.53 \%$ & $1.62 \%$ & $5.25 \%$ & $7.28 \%$ \\
\hline & st. dev. & $3.67 \%$ & $3.51 \%$ & & & \\
\hline & $\mathrm{N}$ & 36 & 48 & & & \\
\hline
\end{tabular}


Table 7

Bond Yields in the United States and London

Illinois, Massachusetts, and Indiana Bonds

$\begin{array}{cccc}\text { Illinois } & \text { Illinois } & \text { MA } & \text { Indiana } \\ \text { London } & \text { US } & \text { London } & \text { London }\end{array}$

\begin{tabular}{|c|c|c|c|c|}
\hline 1831 mean & --- & --- & --- & --- \\
\hline st. dev. & --- & --- & --- & --- \\
\hline $\mathrm{N}$ & 0 & 0 & 0 & 0 \\
\hline mean & --- & --- & --- & --- \\
\hline st. dev. & --- & --- & --- & --- \\
\hline $\mathrm{N}$ & 0 & 0 & 0 & 0 \\
\hline mean & $4.35 \%$ & --- & --- & --- \\
\hline st. dev. & $0.00 \%$ & --- & -- & --- \\
\hline $\mathrm{N}$ & 10 & 0 & 0 & 0 \\
\hline mean & --- & --- & -- & $4.27 \%$ \\
\hline st. dev. & --- & --- & --- & $0.01 \%$ \\
\hline $\mathrm{N}$ & 0 & 0 & 0 & 23 \\
\hline mean & $5.28 \%$ & --- & --- & $5.11 \%$ \\
\hline st. dev. & $0.00 \%$ & --- & -- & $0.45 \%$ \\
\hline $\mathrm{N}$ & 1 & 0 & 0 & 28 \\
\hline mean & --- & --- & -- & $5.97 \%$ \\
\hline st. dev. & --- & --- & --- & $0.18 \%$ \\
\hline $\mathrm{N}$ & 0 & 0 & 0 & 24 \\
\hline 1837 & --- & --- & --- & $6.19 \%$ \\
\hline Q2 & --- & --- & --- & --- \\
\hline Q3 & --- & --- & --- & $7.07 \%$ \\
\hline Q4 & --- & --- & --- & $6.93 \%$ \\
\hline st. dev. & & & & $0.38 \%$ \\
\hline $\mathrm{N}$ & 0 & 0 & 0 & 57 \\
\hline
\end{tabular}




$\begin{array}{rrrrrr}1838 & \text { Q1 } & --- & --- & 4.05 \% & 6.37 \% \\ & \text { Q2 } & 5.65 \% & 4.89 \% & --- & 6.45 \% \\ & \text { Q3 } & 5.64 \% & --- & 4.39 \% & 6.79 \% \\ & \text { Q4 } & --- & --- & 4.41 \% & 5.71 \% \\ & \text { st. dev. } & 0.02 \% & 0.03 \% & 0.07 \% & 0.48 \% \\ & \text { N } & 26 & 4 & 26 & 45 \\ 1839 & & & & & \\ & \text { Q1 } & 5.83 \% & 5.69 \% & 4.42 \% & 5.92 \% \\ & \text { Q2 } & 5.89 \% & --- & 4.68 \% & 5.92 \% \\ & \text { Q3 } & --- & 5.92 \% & 4.06 \% & --- \\ & \text { Q4 } & --- & 10.81 \% & 5.95 \% & 8.76 \% \\ & \text { st. dev. } & 0.06 \% & 2.69 \% & 0.66 \% & 0.96 \% \\ & \text { N } & 25 & 9 & 38 & 23 \\ & & & & & \\ & \text { Q1 } & 7.10 \% & 10.88 \% & --- & --- \\ & \text { Q2 } & 7.32 \% & 8.89 \% & --- & 8.41 \% \\ & \text { Q3 } & 7.67 \% & 8.80 \% & 4.84 \% & 8.10 \% \\ & \text { Q4 } & 8.05 \% & 7.97 \% & 4.91 \% & 8.22 \% \\ & \text { st. dev. } & 7.36 \% & 8.76 \% & 4.88 \% & 8.16 \% \\ \text { st. dev. } & 0.01 \% & 9.82 \% & 0.09 \% & 3.03 \% \\ & \text { N } & 5 & 37 & 9 & 10\end{array}$




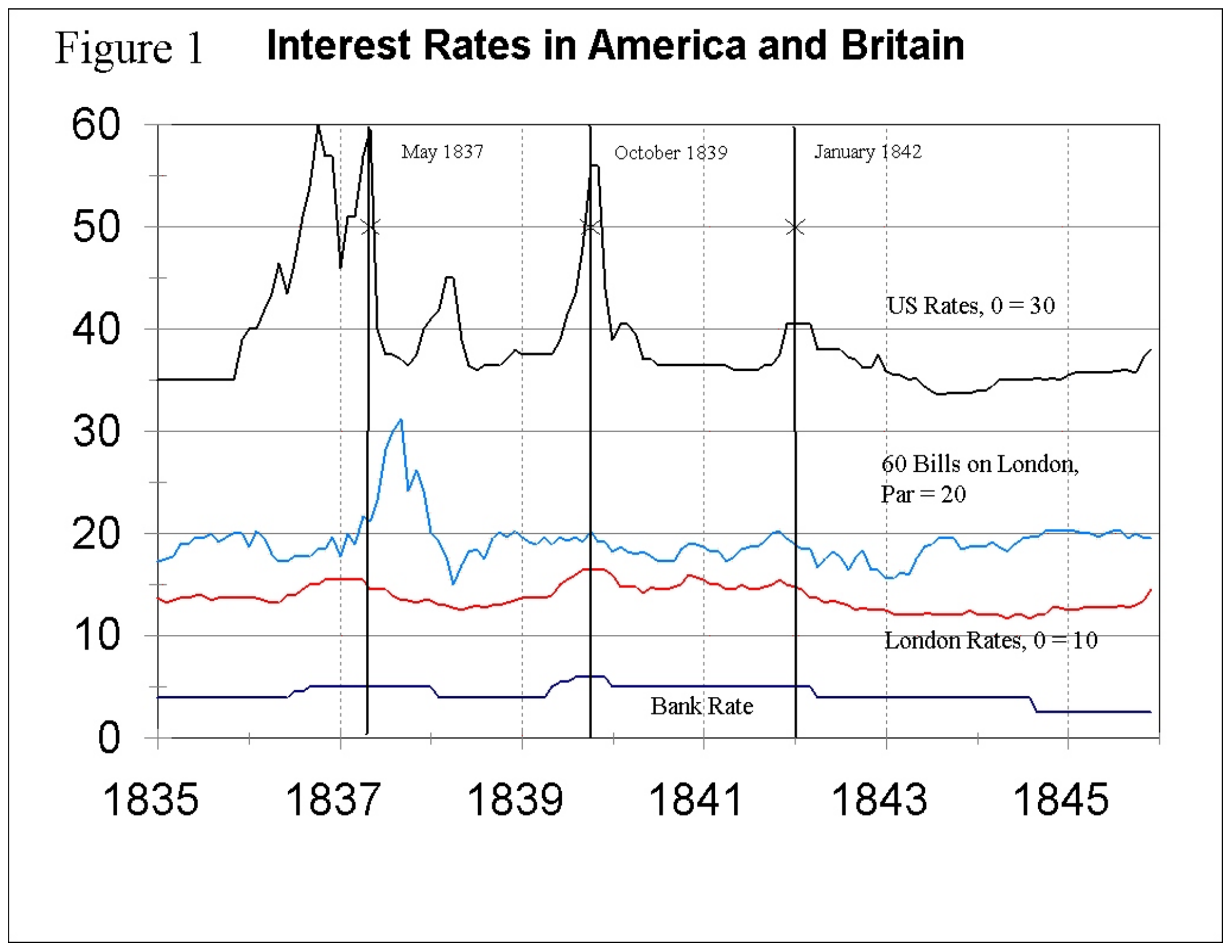


Figure 2

\section{US Bond Yields in London}

Average Yields, Six states

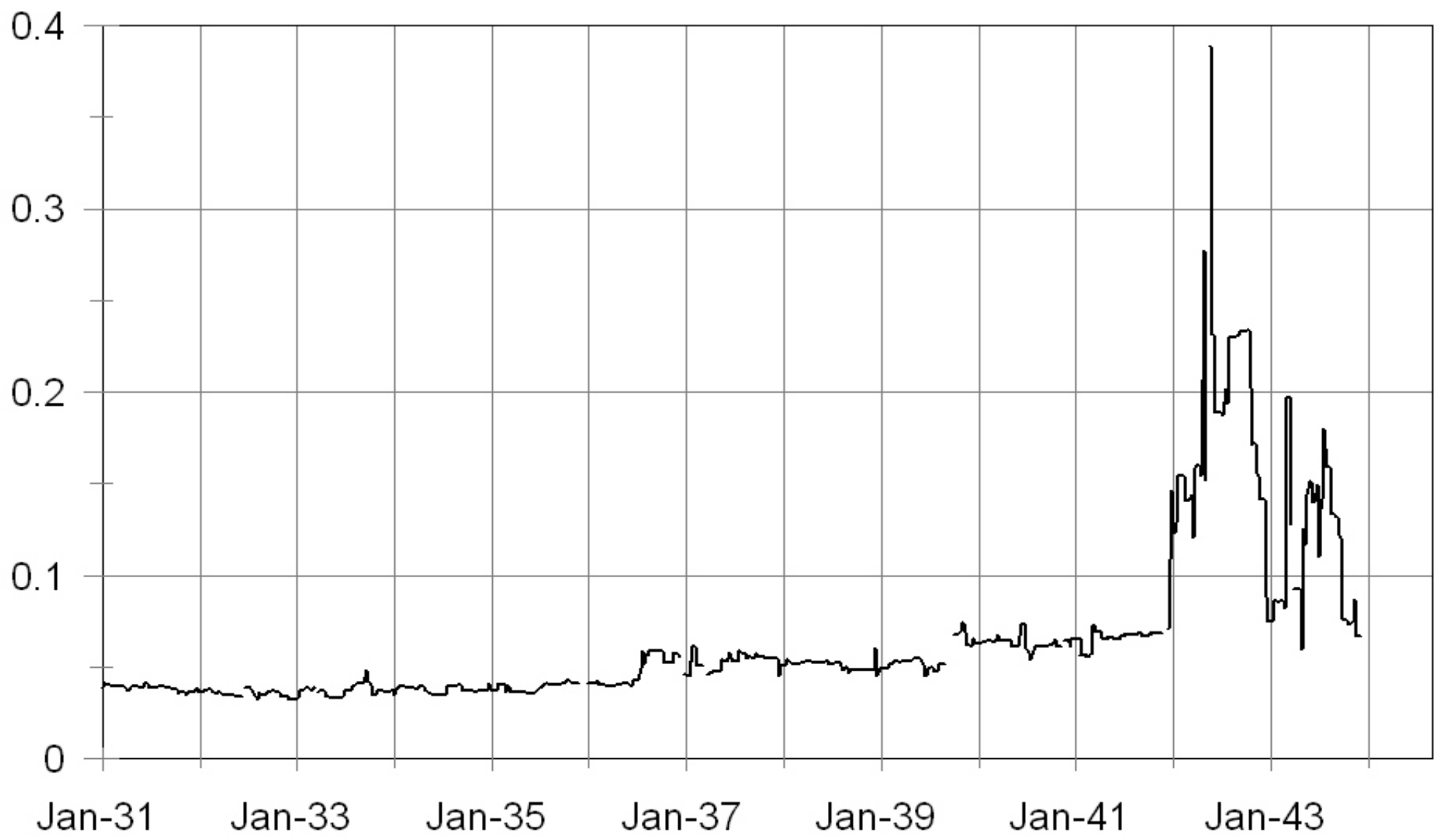




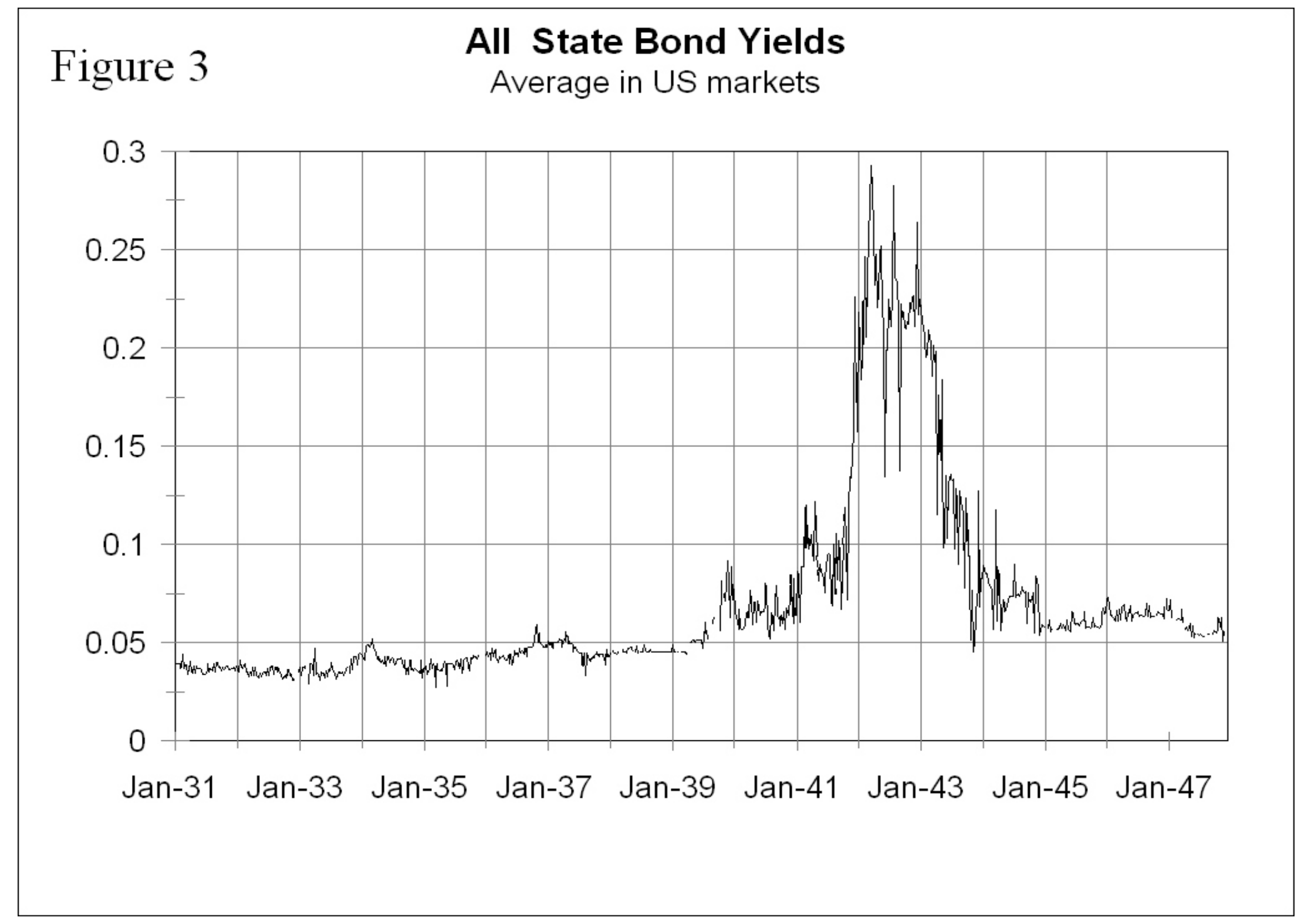




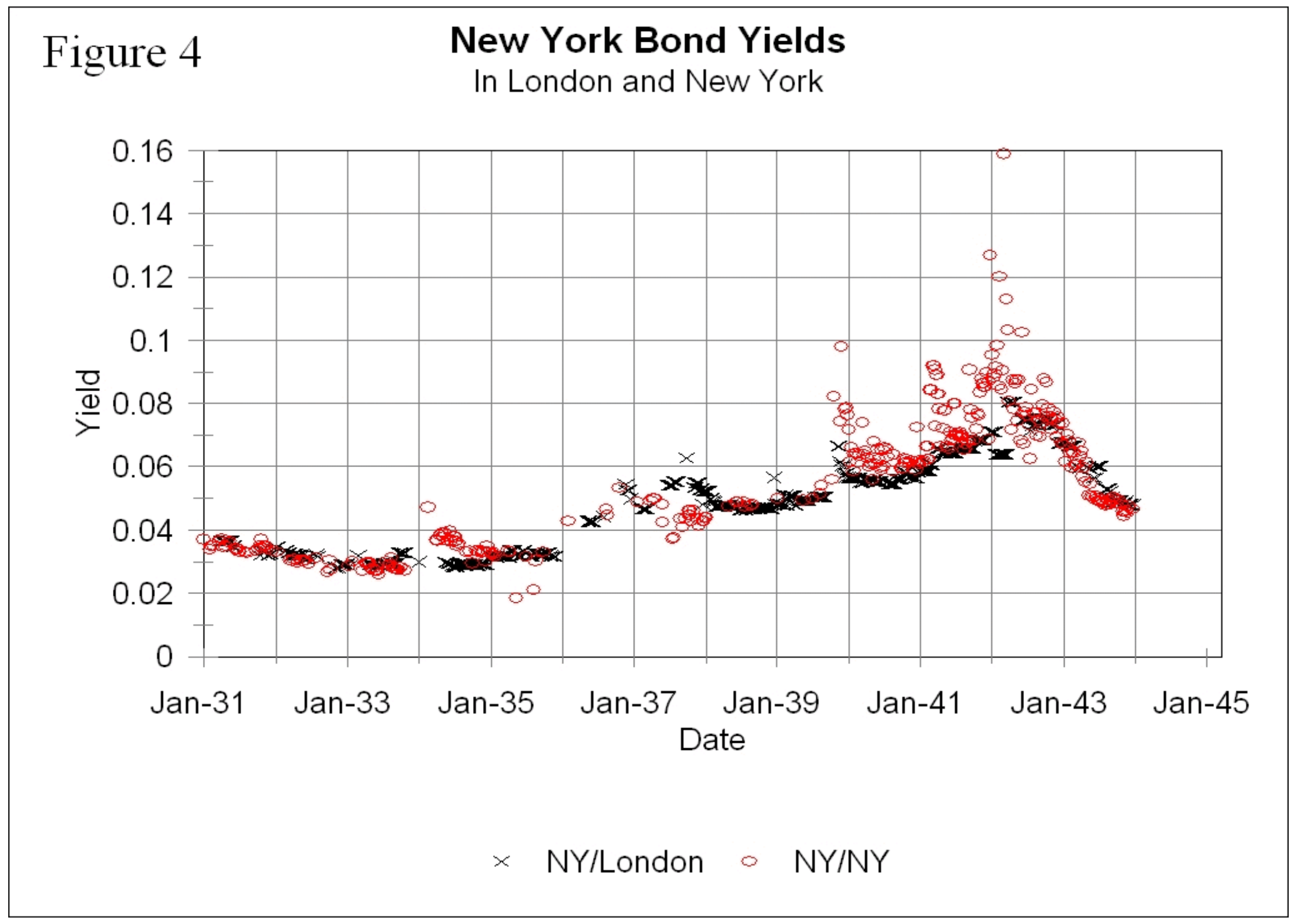




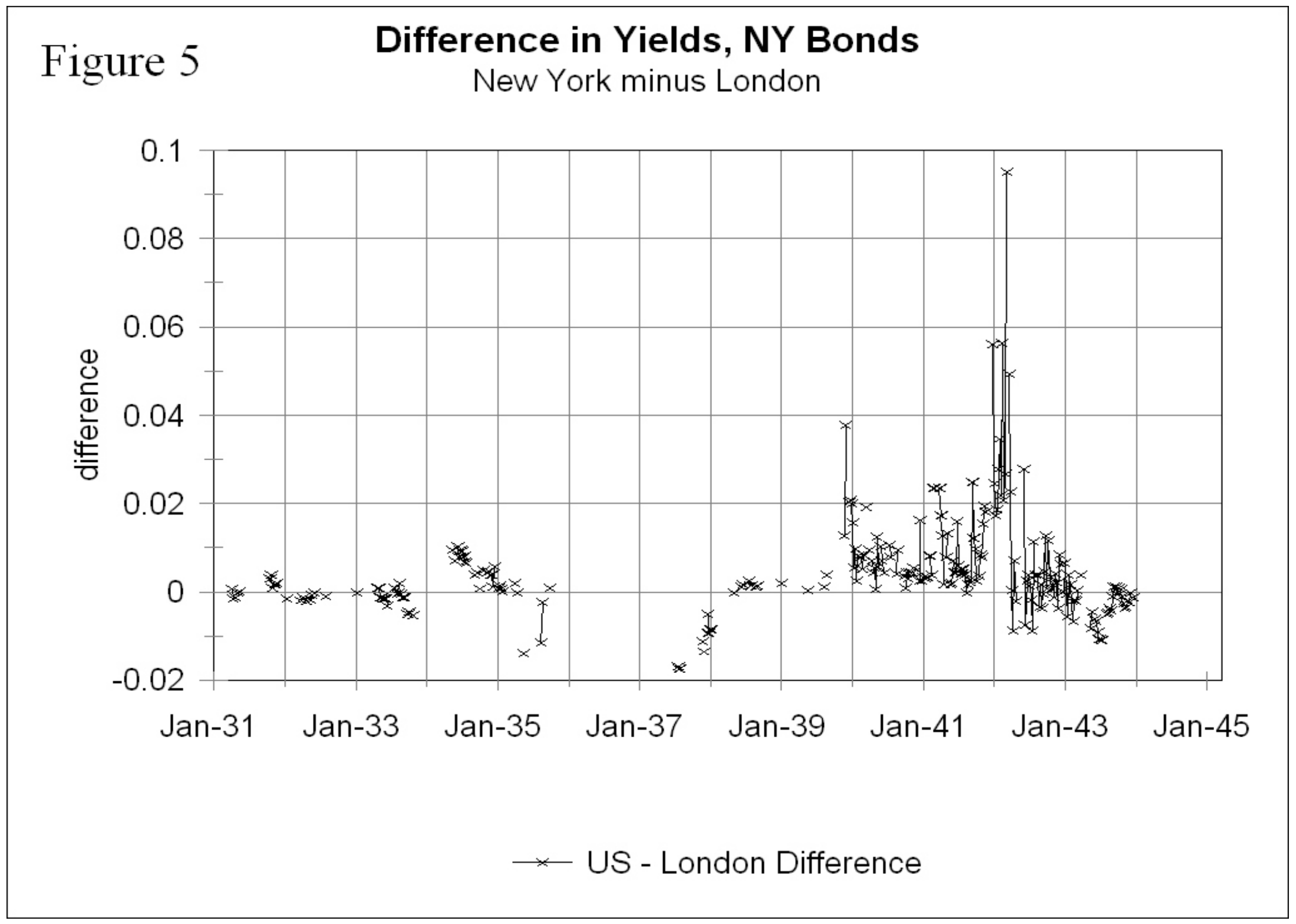




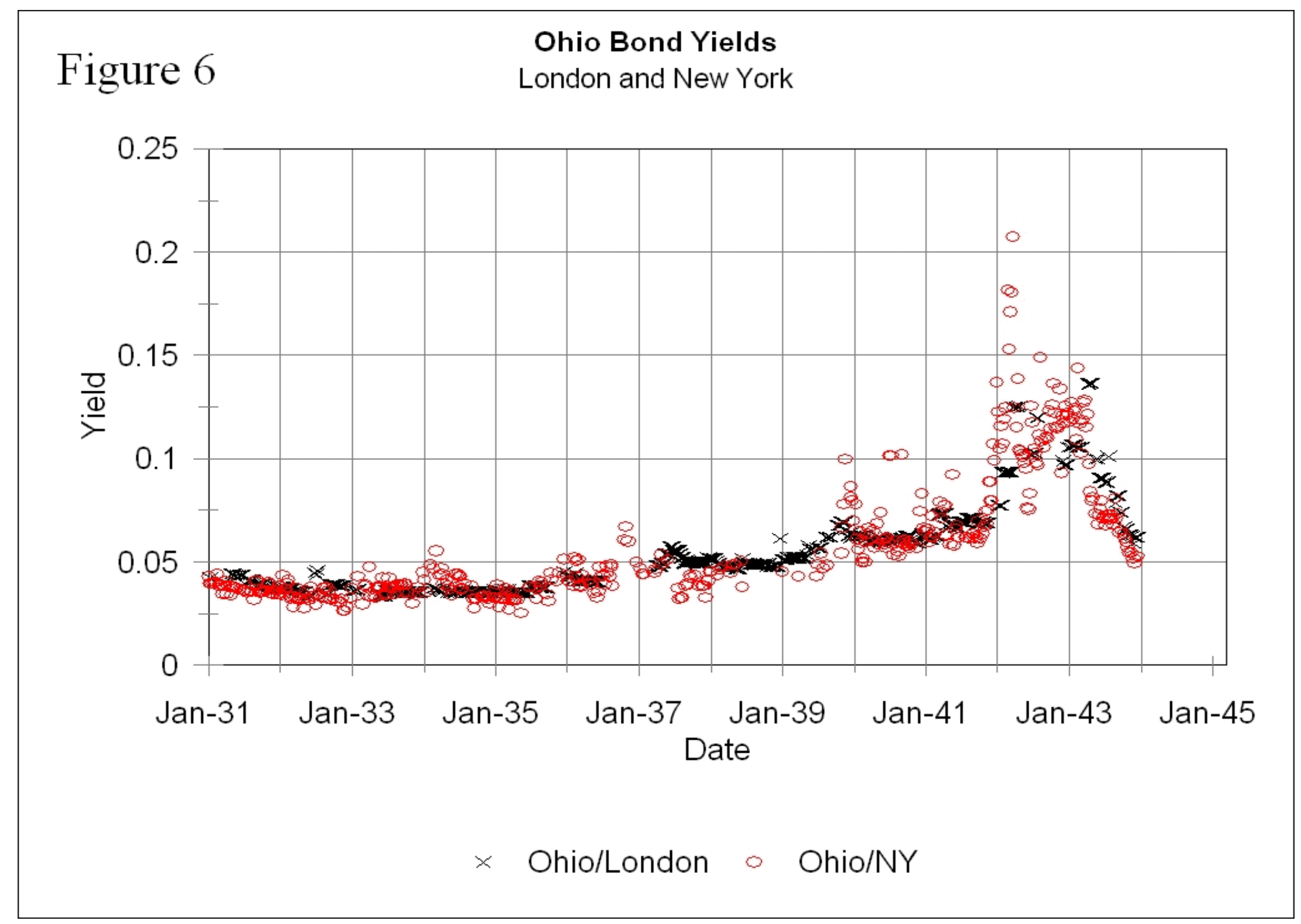




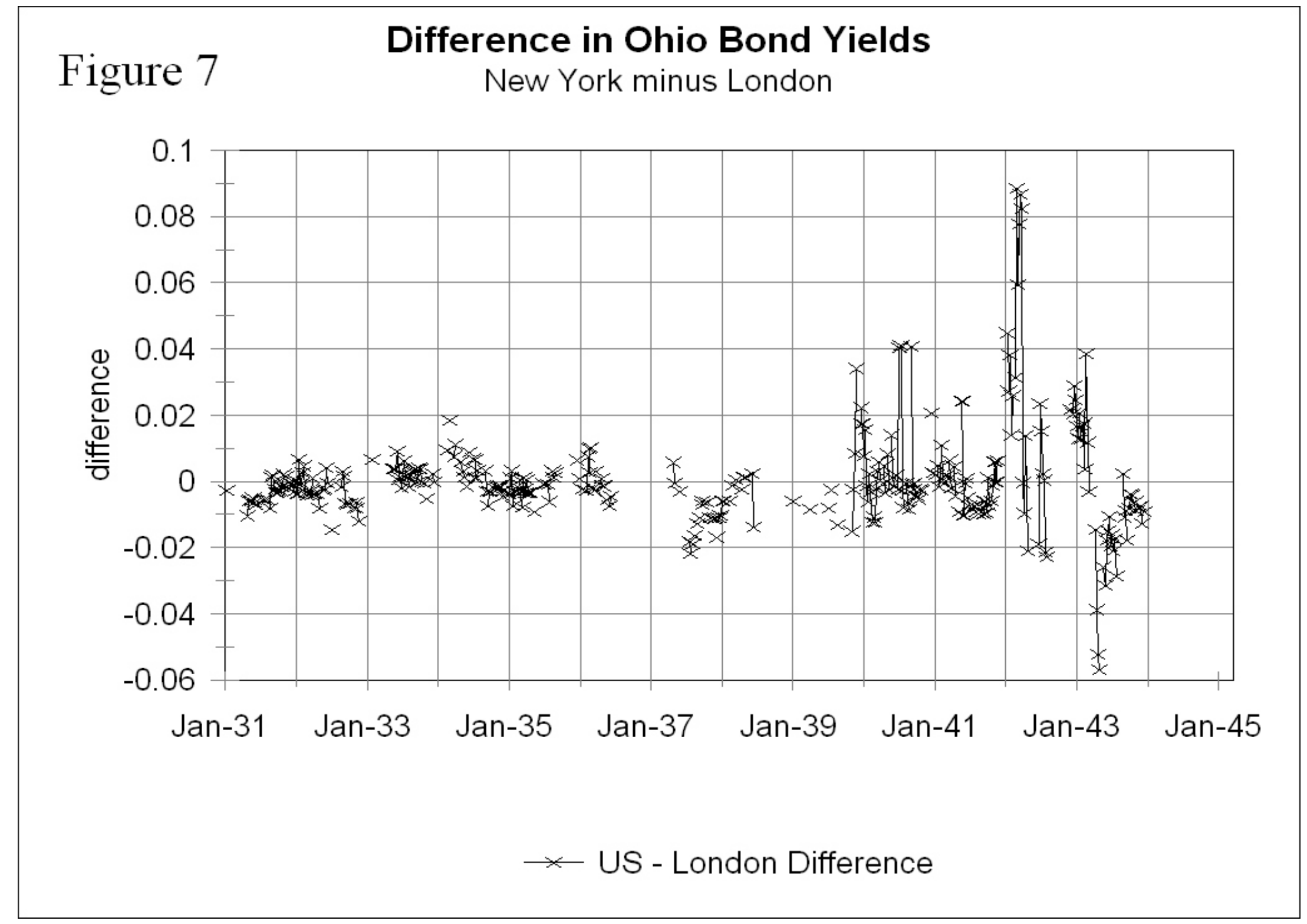




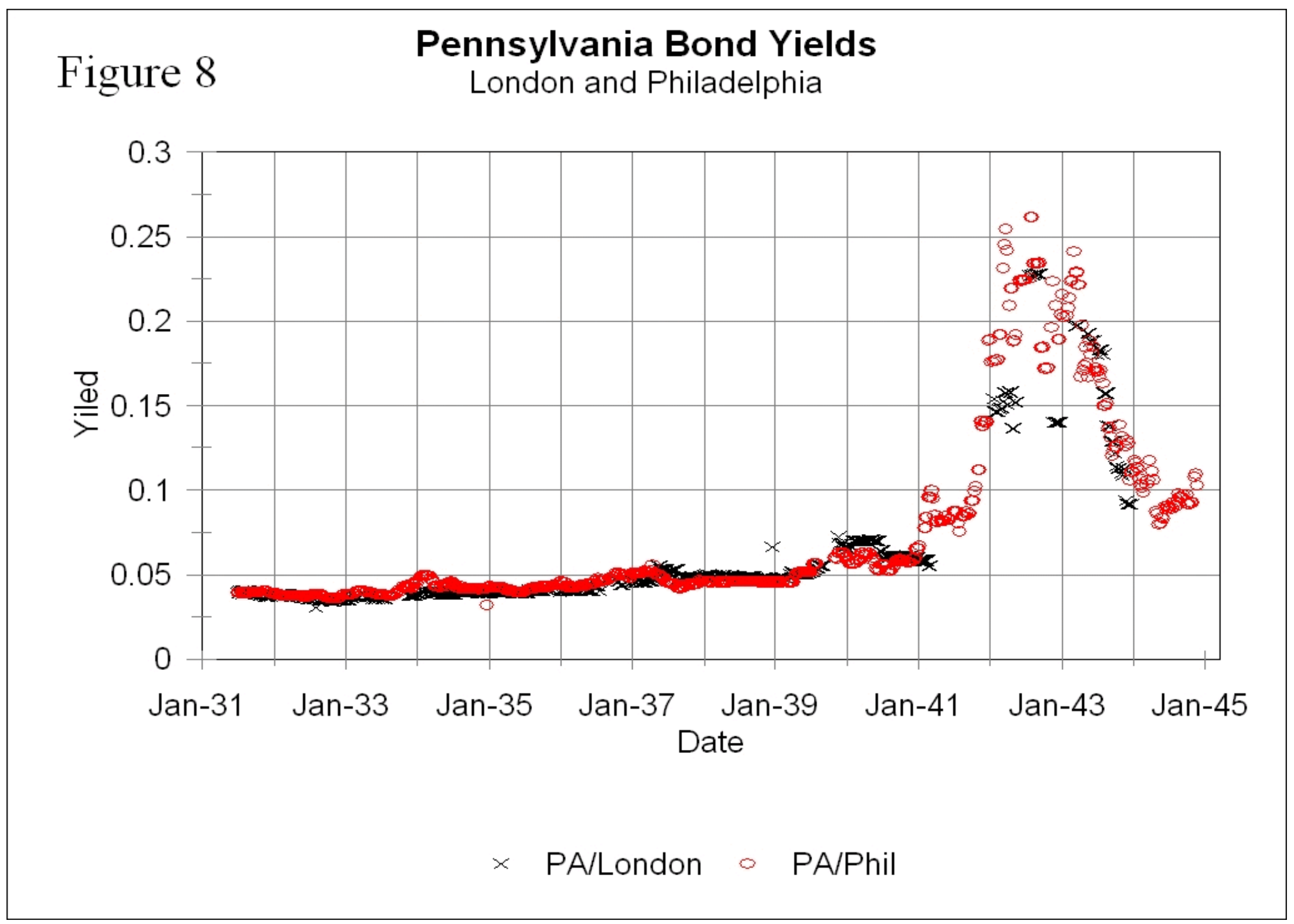




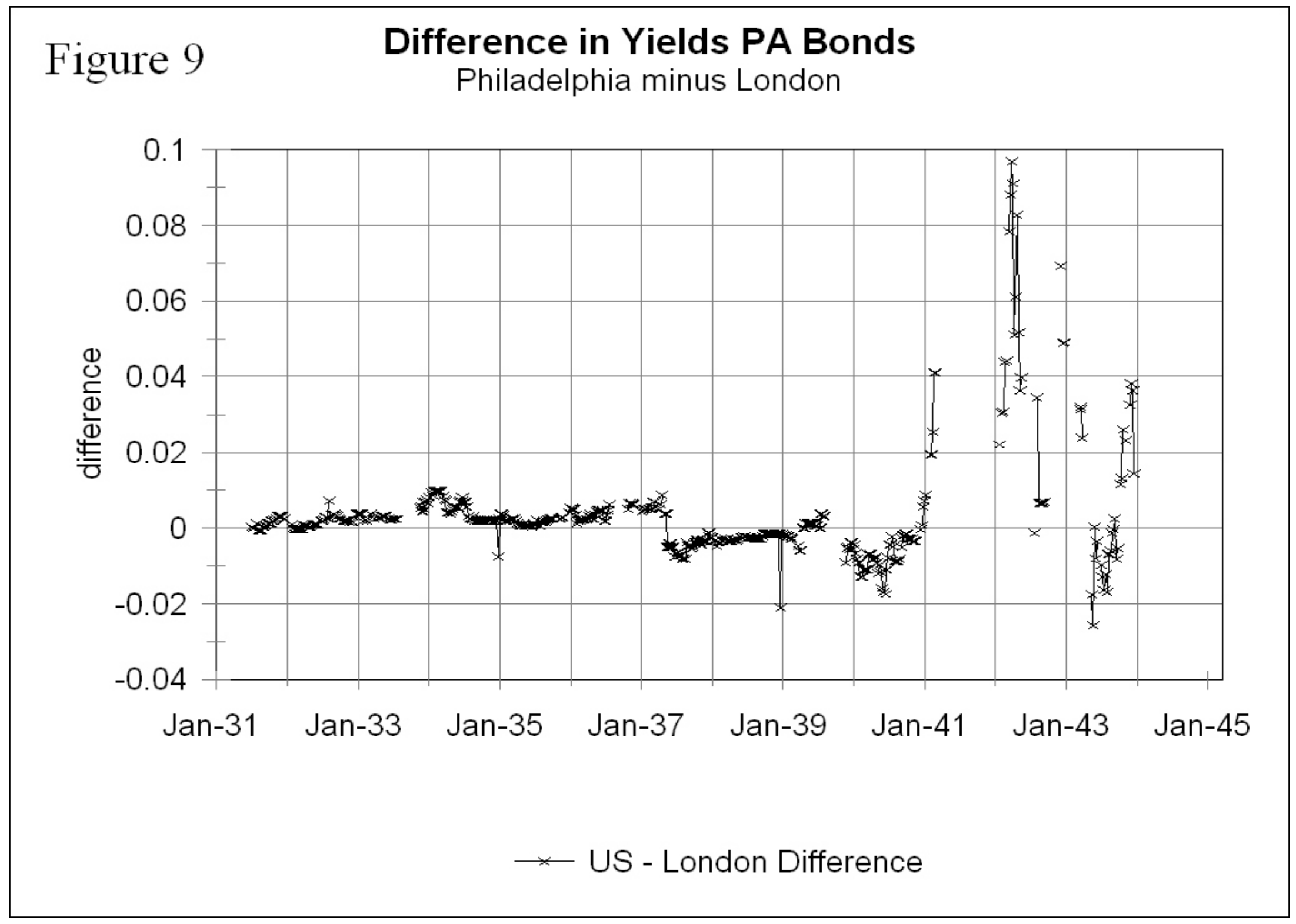




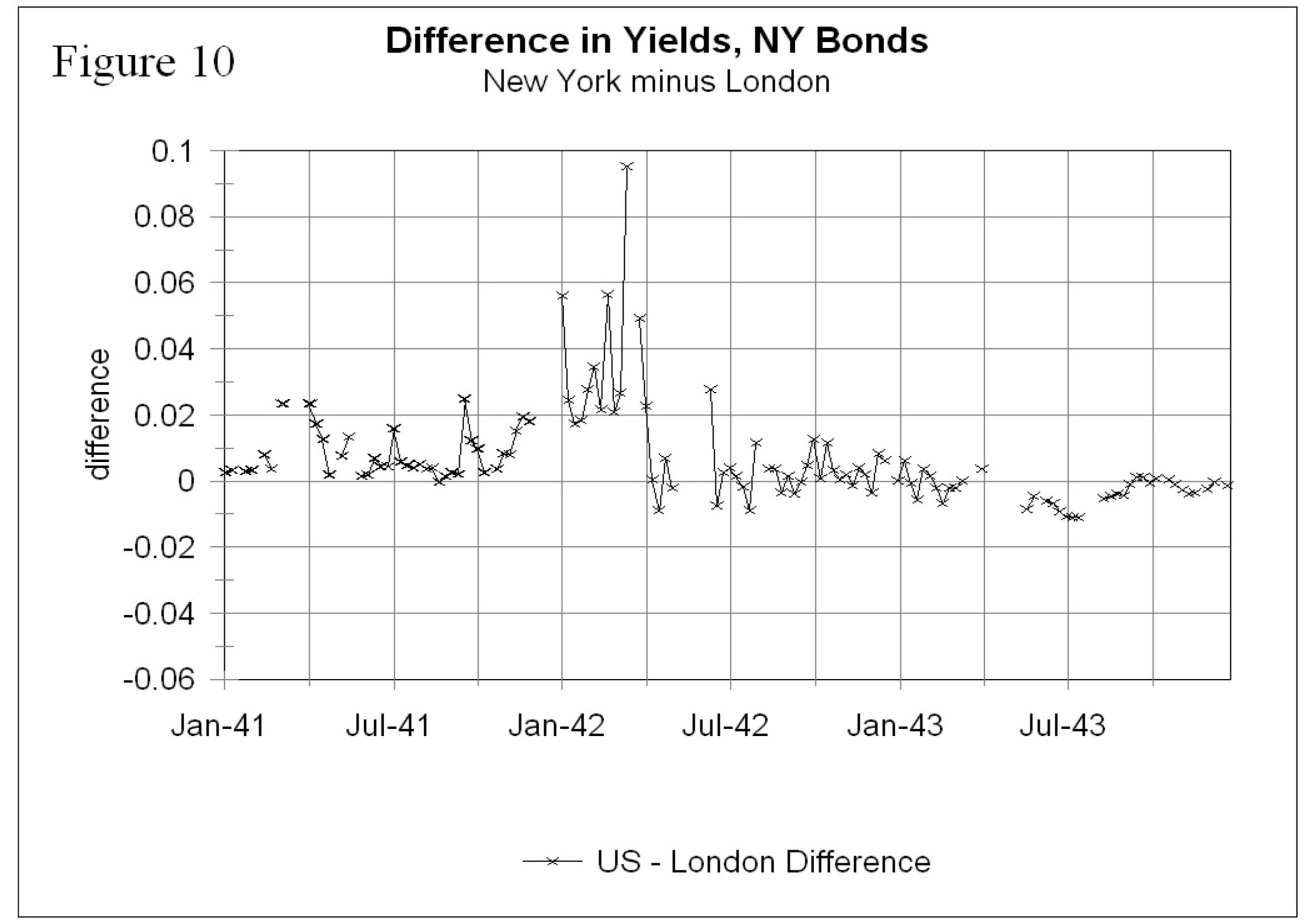




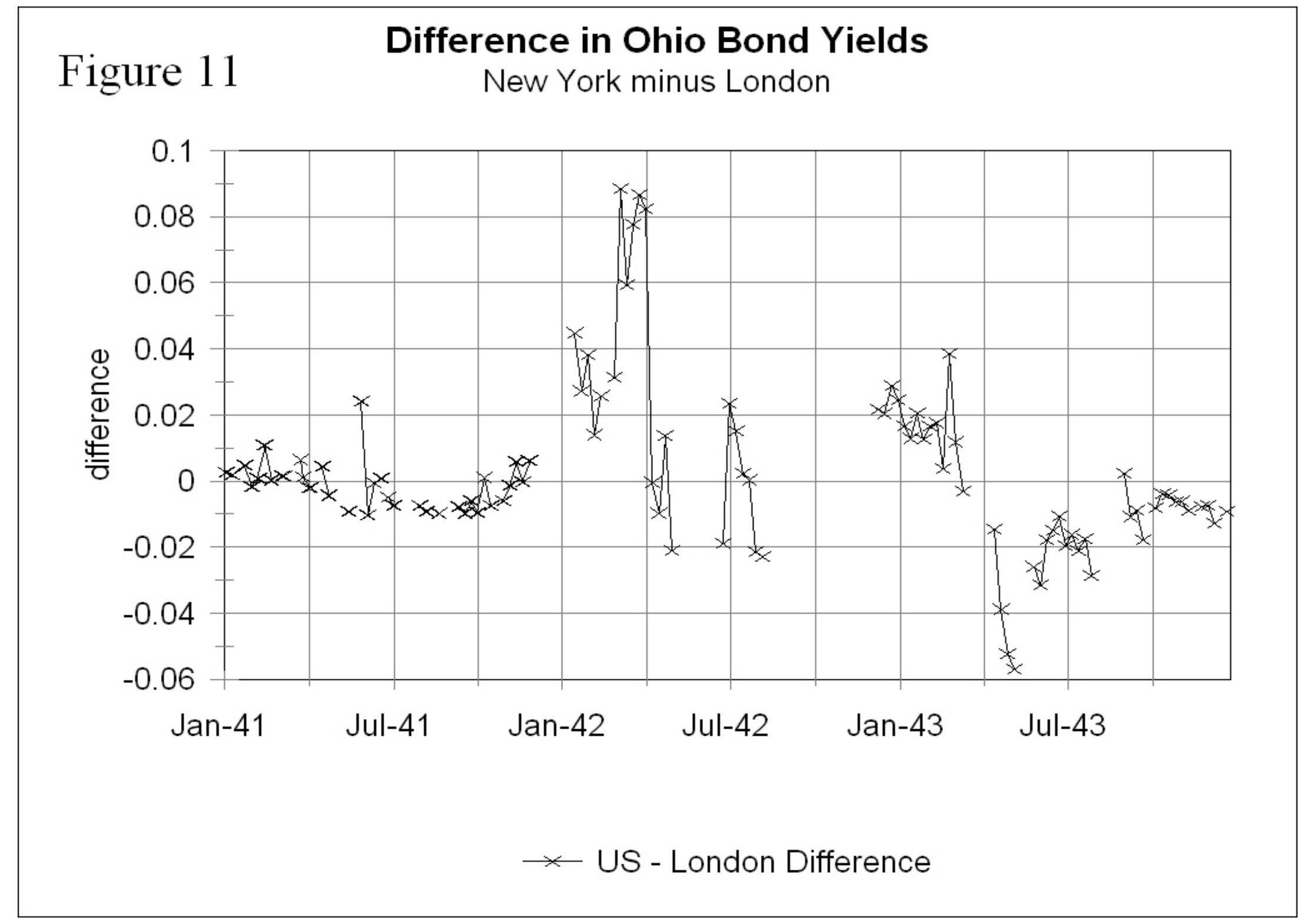




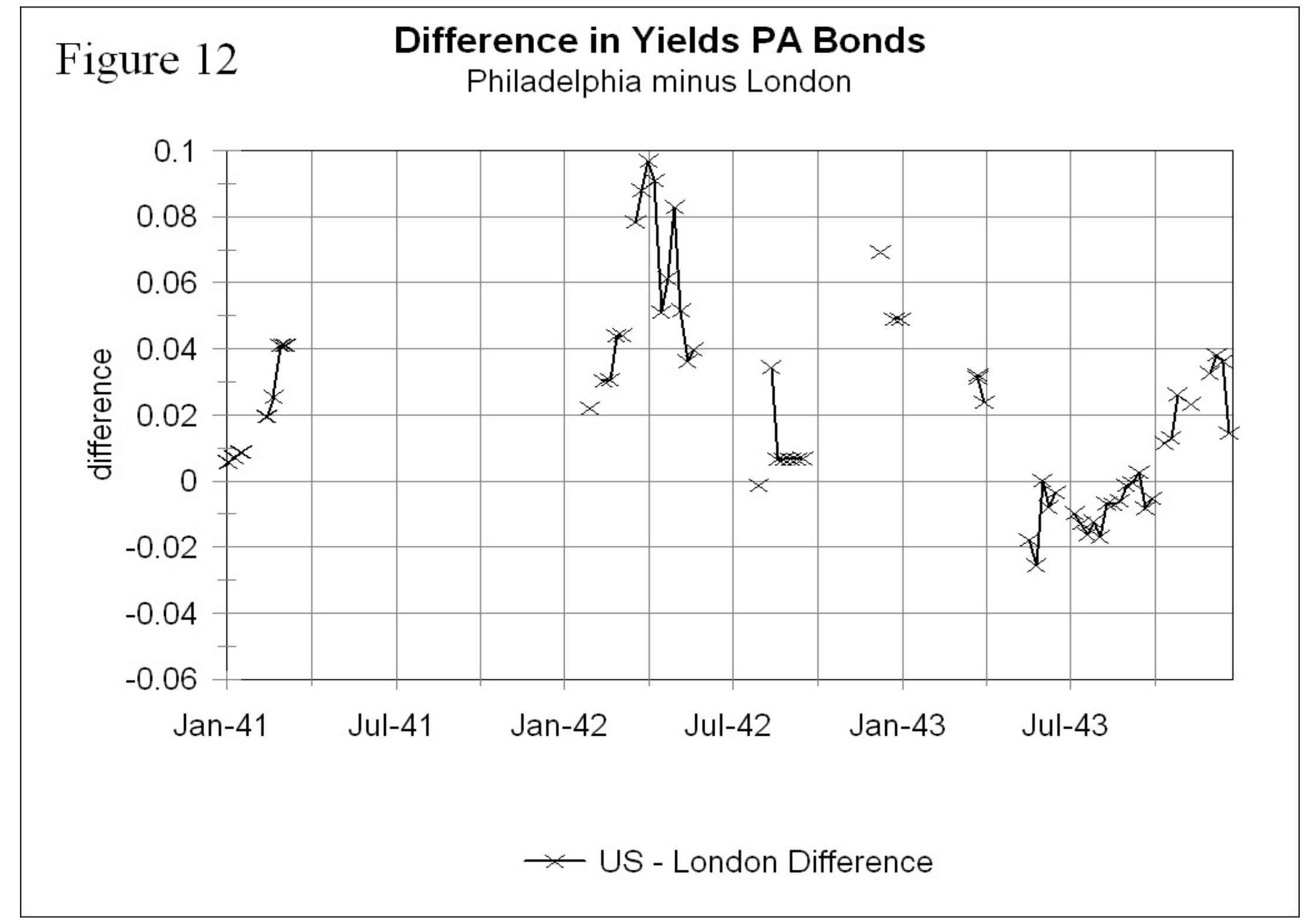


Notes to Figures and Tables:

Figure 1: Interest rates in the New York and Boston are the average of the high and low rates reported in Smith and Cole, Fluctuations, Table 74, pp. 192-3.

Interest rates in London: From National Bureau of Economic Research.

Bank Rate: Clapham, Bank of England, vol II, Appendix B, p. 199.

Exchange Rates on 60 day bills, Smith and Cole, Fluctuations, p. 190 and Officer, "Integration in the American Foreign Exchange Market," p. 563.

Figures 2 through 11: Sylla, Wilson, and Wright, Price Quotations.

Table 1: “The William Cost Johnson Report.” House Report, 296, 27th Congress, 3rd Session, 1843.

The numbers for Ohio in the Johnson report are unreliable for the later years. We include Scheiber's, Ohio Canals, estimates of borrowing for 1840 and 1841, pp. 143-151, and the \$20 million figure cited in the Census of 1880 .

Table 2: English, "Sovereign Default.”

Tables 5 through 7: Sylla, Wilson, and Wright, Price Quotations. 
Appendix to Kim and Wallis:

The Market for American State Government Bonds in Britain and the United States, 1830 to 1843.

Our multivariate $\mathrm{ARCH}$ model for market integration tests int the bond and stock markets is:

$$
\begin{aligned}
& Y_{i t}=X_{i t} B_{i}+\varepsilon_{i t} \quad, i=1,2, \cdots, n \\
& \varepsilon_{t} \mid \Lambda_{t-1} \sim N\left(0, \Omega_{t}\right) \\
& E\left(\varepsilon_{i t} \mid \Lambda_{t-1}\right)=0 \\
& E\left(\varepsilon_{i t} \varepsilon_{j t} \mid \Lambda_{t-1}\right)=\Omega_{i j t}=a_{i j}+b_{i j} \varepsilon_{i t-1} \varepsilon_{j t-1}
\end{aligned}
$$

Where $\Lambda_{t-1}$ is the information set in time $\mathrm{t}-1$. In the text, $\mathrm{X}$ contains only a constant term and $\mathrm{n}$ is equal to two. We maximizing the following log likelihood function to estimate the parameters, a, b, and B:

$$
\begin{aligned}
& \log L=-\sum_{t=1}^{T} \frac{n}{2} \log (2 \pi)-\sum_{t=1}^{T} \frac{1}{2} \log \left|\Omega_{t}\right|-\sum_{t=1}^{T} \frac{1}{2} \varepsilon_{t}^{\prime} \Omega_{t}^{-1} \varepsilon_{t} \\
& \text { where } \\
& \Omega_{t}=\Omega_{t}(a, b, B) \text { and } \Omega_{i j t}=a_{i j}+b_{i j} \varepsilon_{i t-1} \varepsilon_{j t-1} \\
& \varepsilon_{t}=Y_{t}-X_{t} B \\
& \therefore \log L=\log L(a, b, B \mid \text { data })
\end{aligned}
$$

Because the bond prices are not complete, we have missing data in the dependent variable. For our bench mark results, we linearly interpolated bond prices on the surrounding observations. This imputed series is used for the ARCH estimation. For example, if prices are available in week 3 and week 5 in London, we linearly interpolate between the two prices to obtain an estimate for week 4.

This imputation causes a consistency problem in our estimates, since the imputation is not likely to be the true data generating process. We can get around this problem by iterating an 
EM algorithm process. Imputation is the first step of the EM algorithm. The standard second step is to maximize the likelihood function to get parameter estimates, and then go back to the first step to reimpute the data using the estimates. By iterating these two steps, the estimates converges to the true values in the limit. Instead, we develop a new method to estimate the missing observations directly. It is easier and faster than the EM algorithm iteration.

Suppose an observation is missing at time $\mathrm{t}-1$. For example, the data are not available in London in week 4 , while the data are available in week 3 and week 5 in both markets. We take the covariance matrix of time $t$, conditional on time $t-2$ disturbance terms, instead of time $t-1$ disturbance terms. That is, the covariance of week 5 is conditional on week 3 data, not week 4 data:

$$
\begin{aligned}
& E\left(\varepsilon_{i t} \varepsilon_{j t} \mid \Lambda_{t-2}\right)=a_{i j}+b_{i j} E\left(\varepsilon_{i t-1} \varepsilon_{j t-1} \mid \Lambda_{t-2}\right) \\
& E\left(\varepsilon_{i t-1} \varepsilon_{j t-1} \mid \Lambda_{t-2}\right)=a_{i j}+b_{i j} \varepsilon_{i t-2} \varepsilon_{j t-2} \\
& \therefore E\left(\varepsilon_{i t} \varepsilon_{j t} \mid \Lambda_{t-2}\right)=a_{i j}\left(1+b_{i j}\right)+b_{i j}^{2} \varepsilon_{i t-2} \varepsilon_{j t-2}
\end{aligned}
$$

In this fashion, we can represent the conditional covariance of time $t$ with the time $t-2$ error terms. Generalizing this method recursively to the case where time (t-s) data are the latest data observed before t, we get

$$
\begin{aligned}
& E\left(\varepsilon_{i t} \varepsilon_{j t} \mid \Lambda_{t-s}\right)=a_{i j}^{*}+b_{i j}^{*} \varepsilon_{i t-s} \varepsilon_{j t-s} \\
& \text { where } \\
& \left\{\begin{array}{l}
a_{i j}^{*}=a_{i j}\left(1+b_{i j}+\cdots+b_{i j}^{s-1}\right) \\
b_{i j}^{*}=b_{i j}^{s}
\end{array}\right.
\end{aligned}
$$

Therefore, $\left(a^{*}, b^{*}\right)$ has one-to-one nonlinear relationship to $(a, b)$. Using this relationship, we can adjust the likelihood function without changing the number of parameters we are estimating: 


$$
\begin{aligned}
& \log L=-\sum_{t \in A} \frac{n}{2} \log (2 \pi)-\sum_{t \in A} \frac{1}{2} \log \left|\Omega_{t}\right|-\sum_{t \in A} \frac{1}{2} \varepsilon_{t}{ }^{\prime} \Omega_{t}^{-1} \varepsilon_{t} \\
& \text { where } \\
& \Omega_{t}=\Omega_{t}(a, b, B) \text { and } \Omega_{i j t}=a_{i j}\left(1+b_{i j}+\cdots+b_{i j}^{s-1}\right)+b_{i j}^{s} \varepsilon_{i t-s} \varepsilon_{j t-s} \\
& \varepsilon_{t}=Y_{t}-X_{t} B \\
& A=\text { time periods when the data are observed } \\
& \therefore \log L=\log L(a, b, B \mid \text { observed data })
\end{aligned}
$$

The covariance matrix is conditional on the latest observations available. The likelihood function is still determined by $\mathrm{a}, \mathrm{b}$ and $\mathrm{B}$ conditional only on the observed data. There is a computational problem because the likelihood function is highly nonlinear on a and $b$, but the consistency of the estimate is preserved. 